dergİabant (AİBÜ İlahiyat Fakültesi Dergisi), Bahar 2019, Cilt:7, Sayı:13, 7:190-219

Gönderim Tarihi: 12.02.2019 Kabul Tarihi: 08.05.2019

Araştırma Makalesi

Doi: https://doi.org/10.33931/abuifd.526366

\title{
GENÇLERDE SINAV KAYGISI, DİNDARLIK VE DUA İLIŞKİSi
}

Necmi KARSLI*

Öz

Günümüzde sınavların bireyin geleceği üzerinde önemli etkisinin bulunması sınav kaygısı sorununa yol açmakta ve bu sorunla başa çımmada psikolojik tedavi yöntemlerinin yanında alternatif bakış açılarına ihtiyaç bulunmaktadır. $\mathrm{Bu}$ araştırmanın amacı genç bireylerde sınav kaygısı, dindarlık ve dua ilişkisini tespit etmektir. Araştırmanın örneklemi Trabzon'da ikamet eden yaşları 16-26 arasında değişen 367'si $(\% 66,1)$ kadın ve 188'i $(\% 33,9)$ erkek toplam 555 genç bireyden oluşmaktadır. Araştırmada veri toplama aracı olarak Sınav Kaygısı Ölçeği, İçsel Dini Motivasyon Ölçeği ve Dini Şuur Ölçeği kullanılmıştır. Araştırmada öncelikle demografik özellikler ile sınav kaygısı ilişkisine bakılmıș, daha sonra sınav kaygısı ile dindarlık ve dua ilişkisi incelenmiştir. Araştırmada elde edilen verilerin analizi sonucunda, cinsiyet ile sınav kaygısı arasında negatif; dini şuur ve alt boyutları ile sınav kaygısı arasında pozitif yönlü ilişki tespit edilmiştir. Ayrıca araştırmada dua ibadetinin sınav kaygısını azaltmada pozitif etkisinin olduğu tespit edilmiştir.

Anahtar Kelimeler: Din psikolojisi, Kaygı, sınav kaygısı, dindarlık, dua.

\section{RELATIONSHIP OF EXAM ANXIETY, RELIGIOUSNESS AND PRAYING IN YOUNG PEOPLE}

\begin{abstract}
Today, having tests important impact on the future of the individual causes test anxiety problem and there is a need for alternative perspectives in addition to psychological treatment methods in coping with this problem. The aim of this study is to determine the relation between exam anxiety, religiousness and prayer in young individuals. The sample of the study consisted of $367(66,1 \%)$ female and 188 $(\% 33,9)$ male totally 555 young people aged between $16-26$ years. Test Anxiety Scale, Internal Religious Motivation Scale and Religious Consciousness Scale were used to collect data. In the study, firstly the relationship between demographic characteristics and test anxiety and then the relationship between test anxiety, religiousness and prayer was examined. As a result of the analysis of the data obtained in the study, it was negative relationship between sex and exam anxiety; A positive relationship was found between religious consciousness and subdimensions and test anxiety. In addition, the study showed that praying has a positive effect on reducing the anxiety of exam.
\end{abstract}

Keywords: Psychology of religion, anxiety, test anxiety, religiousness, praying.

Dr. Öğr. Üyesi, Trabzon Üniversitesi İlahiyat Fakültesi, Felsefe ve Din Bilimleri Bölümü, Din Psikolojisi Anabilim Dall, necmikarsli@hotmail.com

ORCID ID 0000-0002-2975-9307 


\section{Giriș}

Stres, kaygı ve başa çıkma insanlık tarihinin başlangıcından günümüze kadar var olagelen psikolojik durumlardır. İlkel zamanlarda insanlar vahşi hayvanlar, kıtlık, salgın ve doğal felaketler gibi olaylar karşısında stres ve kaygı tecrübe ederlerken günümüz insanı ise eğitim, gelecek, iş, aile, sağlık ile ilgili konularda negatif sonuç ve belirsizliklerin neden olduğu yoğun stres ve kaygı duyguları tecrübe etmektedir. Sınav kaygısı günümüzün en yaygın psikolojik sorunlarından birisidir. ABD'de sınav kaygısı problemi olan öğrencilerin oranı \%20 seviyesinde iken, ülkemizde bu rakam \%65-70 civarındadır. ${ }^{1}$ Günümüzde sinavların bireyin geleceğine dair kararlar üzerinde önemli etkisi bulunmaktadır. Sınavlarda başarılı olmak iyi bir okulda eğitim alma, güzel bir meslek edinme, bunların dolaylı sonucu olarak yüksek bir yaşam standardı ve mutlu bir hayat için zorunlu olarak görülmektedir. Sinavlara bu derece hayati önem atfedilmesi bireylerde sinavlarda başarısız olma korkusu, stres ve kaygı duygularına yol açmaktadır. Sınav kaygısı ve onun diğer psikolojik durum ve değişkenlerle ilişkisine dair pek çok akademik araştırma yapılmış olmasına rağmen dindarlık ile sınav kaygısı ilişkisine dair literatürde çok fazla çalışma bulunmamaktadır. Din, ihtiva ettiği prensip ve öğretiler ile bireye pozitif duygular kazandırırken aynı zamanda yaşamsal olayların yol açtığı stres, kaygı, öfke, gibi negatif duyguların etkilerinden korumaktadır. Bundan dolayı bu araştırma günümüzün en yaygın psikolojik sorunlarından olan sınav kaygısı ile başa çıkmada dua ve dindarlığın etkisini tespit etme açısından önem arz etmektedir.

\section{Kaygı}

Kaygı sözlükte, tehlike veya talihsizlik korkusunun ya da beklentisinin yarattığı bunaltı ve tedirginlik; usdışı korku olarak tanımlanmaktadır. ${ }^{2}$ Kaygı ve korku kavramları birbirinin yerine kullanılmakla birlikte iki kavram aynı şeyler değildir. Kaygıda kaynağı belirsiz bir korku var iken, korku bir tehdit karşısında bedensel tepkiler eşliğinde tecrübe edilen bir duygudur. Izard'a göre kaygl; korku, utanç, öfke ve merak-heyecan gibi duyguları kapsamaktadır. ${ }^{3}$ Amerikan Psikoloji Kurumu'nun Zihinsel Hastalıklar Tanımlama ve İstatistik El Kitabı'na göre kaygı bozukluğu altı ay veya daha uzun süre devam eden ve kontrol etmede güçlük çekilen aşırı korku, kaygı ve bunlarla ilişkili davranışsal bozuklukları içermektedir. ${ }^{4}$

Aslında kaygı en yaygın evrensel insani bir duygulardan birisidir. Kaygının belli seviyede olması bireyin çalışması ve üretmesi için motive edici işlev görmektedir. Pek çok müzisyen, aktör, atlet, mesleklerinin ilk zamanlarında tecrübe ettikleri kaygılarının yüksek enerji ve güven kazandırarak performanslarını artırdığı

İhsan Kurt, Sınav Kaygısını Aşmanın Yolları, İstanbul: Bizim Kitaplar, 2011, s. 137.

Selçuk Budak, Psikoloji Sözlüğ̈̈, Ankara: Bilim ve Sanat Yayınları, 2009, s. 418.

Carroll E. Izard, "Anxiety: A Variable Combination Of Interacting Fundamental Emotions" Anxiety Current Trends in Theory And Research, (ed. Charles D. Spielberger), New York: Academic Press, 1972, 1, 55.

$4 \quad$ American Psychiatric Association, Diagnostic And Statistical Manual Of Mental Disorders, (5. Baskı), Washington: American Psychiatric Association, 2013, s. 189,190. 
ve kendilerini daha ileriye götürdügünü ifade etmiştir. Pozitif kaygı güven duygusu ile birlikte performansı artırabilirken, sürekli ve kontrol edilemeyen kaygı bir probleme dönüşmekte ve bireyin yaşam kalitesi, sağlığ mesleki performansı üzerinde olumsuz etkilere yol açabilmektedir. ${ }^{5}$ Kaygının temelinde genler, çocukluk tecrübeleri, biriktirilmiş stres, şartlanma, sakıngan davranışlar, kendi kendisiyle olumsuz konuşma, yanlış inançlar, duyguların inkârı, özgüven eksikliği, yanlış beslenme, stresli yaşam tarzı, anlam ve amaç eksikliği gibi pek çok faktör yer almaktadır. Bunları genel olarak, içgüdüsel, biyolojik, davranışsal ve bilişsel etkenler şeklinde sınıflandırabiliriz.

Evrimsel bakış açısından kaygı canlıların hayatta kalma amacına hizmet etmektedir. Darwin duygu ifadelerinin sosyal gruptaki diğer üyelere yakındaki tehlikeden kaçma veya onu önleme konusunda mesaj göndererek hayatta kalma amacına hizmet ettiğini fark etmiştir. Darvin'e göre yüz ifadeleri kaygı ile ilişkilidir, bu da diğerlerini yakın bir tehlike hakkında uyarma ve bilgilendirme işlevi görmektedir.6 Psikanalitik yaklaşım bilinçdışı korkuların, tutkuların ve motivasyonların düşünce ve davranış üzerindeki etkisine dikkat çekmektedir.7 Yaklaşıma göre kaygı, idin ilkel istekleri ile süperegonun ahlaki hedefleri arasında yaşanan çatışmadan doğan rahatsız edici bir duygudur. İdden gelen haz arayışı ile süper egonun onu engellemesi çatışmaya neden olur, kişiliğin arabulucu yönü olan ego ise id ile süperego arasında arabulucu görevi üstlenir ancak egonun bu girișimi kaygıya yol açar. Freud kaygıyı nesnel kaygı, nevrotik kaygı ve ahlaki kaygı şeklinde üç kısımda ele almıştır. Nesnel kaygının kökenleri gerçek dünyadadır ve gerçekten tehlikeli bir durum mevcut olduğunda bu tür bir kaygı tecrübe edilmektedir. Nevrotik kaygı bilinçdışı unsurların bilinç alanına girme tehdidinden doğmaktadır ve cinsel kaynaklıdır. Bu görüşe göre pek çok kaygı daha derin kaygıları, özellikçe bilinçdışından gelen cinsel içerikli olanları bastırma işlevi görmektedir. Ahlaki kaygı ise içselleştirilmiş değerler veya ahlaki kodların ihlal edilme anında veya ihlal edildiğinde tecrübe edilmektedir. ${ }^{8}$ Bilişsel yaklaşım içsel zihinsel süreçleri vurgulayan, davranışın sadece gözle gözlenen yanıyla açıklanamayacağını, altta yatan zihinsel olaylar, temsiller, inançların da açılanması gerektiğini savunmaktadır. ${ }^{9}$ Bilişsel yaklaşıma göre bir düşünce ürünü olan kaygının oluşumunda olayların gerçekçi olmayan bir şekilde yorumlama ve anlamlandırmanın etkisi bulunmaktadır. Kaygı bozukluğu olan bireylerde sorunla başa çıkmada öz güven eksikliği, tehdidin boyutu ile ilgili doğru bilgiye ulaşamama, mantıklı, yapıcı ve gerçekçi düşünememe, kontrol edilemeyen otomatik düşünceler ve sürekli kendine odaklanma tehdit veya tehlike hakkında gerçek dışı inançlar faal

\footnotetext{
$5 \quad$ Cheryl Winning Ghinassi, Anxiety, Oxford: Abc Clio, 2010, s. 5.

6 Charles Darwin, The Expression of the Emotions in Man and Animals, (edt. Francis Darwin), New York: Cambridge University Press, 2009, s. 11-13.

Rod Plotnik, Psikolojiye Giriş, (çev. Tamer Geniş), İstanbul: Kaknüs Yayınları, 2009, s. 9.

Sigmund Freud, Interpretion of Dreams, New York: Courier Dover Publications, 2015, s. 413; Moshe Zeidner - Gerald Matthews, Anxiety 101, New York: Springer Publishing, 2010, s. 82; Plotnik, Psikolojiye Giriş, s. 437.

$9 \quad$ Budak, Psikoloji Sözlüğü, s. 130.
} 
bir şekilde bulunmakta, bireyin duygu, düşünce ve davranışlarını etkilemektedir. ${ }^{10}$ Sosyal Öğrenme Yaklaşımı davranışın büyük ölçüde gözlem ve taklitle oluştuğunu savunmaktadır. ${ }^{11}$ Yaklaşıma göre kaygı ve korku genel olarak şartlanma veya diğer öğrenme süreçleriyle edinilmekte ve bunlar sırasıyla kaçma ve kaçınma davranışlarını üretmektedir.12 Buna göre herhangi bir nötr uyarıcı, koşullanma yoluyla koşulsuz bir korku veya kaygı uyarıcısı haline gelebilmektedir. ${ }^{13}$ Duygu koşullanmasına en meşhur örnek psikolog John B. Watson'un 11 aylık erkek bebek Albert üzerinde yaptığı korku koşullanması deneyidir. Deneyde Albert'e beyaz bir fare oyuncağı (nötr uyarıcı) verilir. Daha sonra bebeğe fare verildiğinde ortama rahatsız edici bir gürültülü ses verilir ve Albert ağlar (doğal tepki). Araştırmacı önce oyuncak, sonra ortama hemen gürültü verme işlemini bir süre tekrarlar. Deneyin son aşamasında Albert'e oyuncak fare verilir verilmez Albert korku ile ağlamaya başlar (koşullu tepki). Bu deneyde klasik koşullanma yoluyla Albert'te bir duygu koşullanması gerçekleştirilmiştir. ${ }^{14}$ Nöro-biyolojik yaklaşım, genlerin, hormonların, sinir sisteminin, beynin yapısı, gelişimi ve beyin travmalarının, vücuda giren maddelerin öğrenme, kişilik, bellek, motivasyon duygu, düşünce ve davranış üzerindeki etkilerini incelemektedir. ${ }^{15}$ Yaklaşıma göre kaygı üzerinde özellikle beynin üç bölümünün (hipotalamus, limbik sismtem ve prefrontal korkteks) etkisi bulunmaktadır. ${ }^{16}$ Kaygı bozukluğunda genlerin de etkisi bulunmaktadır. Genlerin kaygı üzerindeki etkisini tespit için aile üyeleri ve ikizler üzerinde yapılan araştırmalarda birinci derece yakınlarında kaygı bozukluğu olanların, ailesinde kaygı bozukluğu olmayanlardan daha yüksek derecede sınav kaygısına sahip oldukları tespit edilmiştir. ${ }^{17}$ İkizler üzerinde yapılan araştırmalarda tek yumurta ikizlerinde kaygı bozukluğu oranı \%12-26 arasında değişirken, çift yumurta

10 Arthur Freeman - Robert A. DiTomasso, "Cognitive Concepts of Anxiety", Textbook of Anxiety Disorders, (edt. Dan J. Stein, Eric Hollander), Washington: American Psychiatric Publishing, 2002, s. 74; David A. Clark - Aaron T. Beck, Cognitive Therapy of Anxiety Disorders, New York: The Guilford Press, 2010, s. 36.

11 Budak, Psikoloji Sözlüğ̈̈, s. 664.

12 Moshe Zeidner, Test Anxiety, The State of The Art, New York: Kluwer Academic Publishers, 1998, s. 157.

$13 \quad$ Zeidner, Matthews, Anxiety 101, s. 86.

14 John B. Watson, Behaviorism, New York: Routledge, 2017, s. 125.

15 Plotnik, Psikolojiye Giriş, s. 6.

16 Zeidner - Matthews, Anxiety 101, s.95; Carolyn Chambers Clark, Living Well With Anxiety, Harpercollins Ebooks, 2006, s. 37.

17 John M. Hettema - Michael C. Neale- Kenneth S. Kendler, "A Review And Meta-Analysis of The Genetic Epidemiology Of Anxiety Disorders", Am J Psychiatry, 158/10 (2001), 1568; Jordan W. Smoller - Felecia E. Cerrato - Sarah L. Weatherall, "The Genetics Of Anxiety Disorders", Anxiety Disorders, (edt. Kerry J. Ressler - Daniel S. Pine - Barbara Olasov Rothbaum), New York: Oxford University Press, 2015, 48; Katharina Domschke - Jürgen Deckert, "Genetics", Behavioral Neurobiology of Anxiety and Its Treatment (edt. Murray B. Stein - Thomas Steckler), New York: Springer, 2010, 63; Peter McGuffin - David Mawson, "Obsessive-Compulsive Neurosis: Two Identical Twin Pairs", British Journal of Psychiatry, 137/3 (1980), 285; Svenn Torgersen, "Genetic Factors in Anxiety Disorders", Arch Gen Psychiatry, 40/10 (1983), 1085. 
ikizlerinde bu oran \%4-15 arasında değişmektedir. ${ }^{18}$ Ayrıca bazı araştırmalar beyin yaralanmalarının genel kaygı bozukluğuna yol açtığını göstermiştir. ${ }^{19}$

\section{Sinav Kaygisı}

Sınav kaygısı bir sınav veya değerlendirilme durumundaki performansa bağlı olarak olumsuz sonuç elde etme olasılığının yol açtığı endişeye eşlik eden bilişsel, duygusal ve davranışsal tepkiler şeklinde tanımlanmaktadır. ${ }^{20}$ Sınav kaygısı üzerine son 60 yıldır çok yoğun araştırmalar yapılmakta bu araştırmalarda sınav kaygısının doğası, bileşenleri, kaynakları, etkenleri, etkileri ve tedavi yöntemleri tespit edilmeye çalışılmaktadır.

Sınav kaygısı bilişsel ve duygusal şeklinde iki boyuttan oluşan çok boyutlu bir yapı olarak kavramsallaştırılmaktadır. Sınav kaygısının bilişsel boyutu, kaygıya neden olan gerçekçi olmayan, anlamsız düşünceleri içermektedir. Bunlar kendine odaklanma, başarısızlığa dair zihinsel meşguliyet, güven eksikliği, sınavla ilgili yetersizlik duyguları, düşük performans beklentileri, başarısızlığın gelecekteki muhtemel sonuçlarını derin derin düşünme gibi unsurlardır. Sınav kaygısının duygusal boyutu ise fizyolojik uyarılmanın neden olduğu otonom bedensel tepkileri içermektedir. Bu otonom tepkiler, kalp atış ve solunum sayısının artması, mide ile ilgili tepkiler, bulantı, terleme, üşüme, ellerin nemlenmesi, idrar boşaltma ihtiyacı, silkelenme ve titremedir. Sınav kaygısında bilişsel ve duygusal boyut birlikte olduğu kadar ayrı ayrı olarak ta tecrübe edilebilmektedir. ${ }^{21}$ Yapılan pek çok araştırmada sınav kaygısının düşük bilişsel performans ve okul başarısı, psikolojik sıkıntı ve hastalıklarla iliş̧ili olduğu tespit edilmiştir. ${ }^{22} \mathrm{Bu}$ araştırmalardan birisi olan Hembree'nin sınav kaygısı, etkileri ve tedavisini inceleyen 562 akademik çalışma üzerinde yaptığı meta analizde sınav kaygısının olumsuz değerlendirilme korkusu,

18 Jordan W. Smoller - Stefanie R. Block - Mirella M. Young, “Genetics Of Anxiety Disorders: The Complex Road From DSM To DNA" Depress Anxiety, 26/11 (2009) 965-975; Hettema vdğr., "A Review And Meta-Analysis of The Genetic Epidemiology of Anxiety Disorders", 1568. Syndromes of Traumatic Brain Injury", NeuroRehabilitation, 17/4, (2002), 345; Rudi Coetzer, Anxiety and Mood Disorders Following Traumatic Brain Injury: Clinical Assessment and Psychotherapy The Brain Injuries Series, New York: Routledge, 2018.

$20 \quad$ Zeidner, Test Anxiety, The State of The Art, s. 25.

21 Zeidner, Test Anxiety, The State of The Art, s. 26,31,40.

22 Eric Gaudry - Donald Spielberger, Anxiety And Educational Achievement, New York: Wiley, 1971; Donald E. Powers, "Test Anxiety and The GRE General Test" Report No. 86-45; Princeton, NJ: Educational Testing Service, 1986, s. 1; Ray Hembree, “Correlates, Causes, Effects, and Treatment of Test Anxiety", Review of Educational Research, 58/1 (1988), 47; Jerrell C.Cassady, Ronald E.Johnson, "Cognitive test anxiety and academic performance" Contemporary Educational Psychology, 27/2 (2002), 270; Süleyman Ertuğrul Tugan, "Lise Öğrencilerinde Sınav Kaygısı ve Akademik Başarı İlișkisi”, Karaelmas Journal of Educational Sciences, 3 (2015) 99; Tuğba Kabalcı, "Akademik Başarının Yordayıcısı Olarak Benlik Saygısı, Sınav Kaygısı ve Sosyo-Demografik Değișkenler" (yüksek lisans tezi, Hacettepe Üniversitesi Sosyal Bilimler Enstitüsü, 2008), s. 67; Fatma Aydın, "Akademik Başarının Yordayıcısı Olarak Akademik Güdülenme, Öz Yeterlilik ve Sınav Kaygısı", (yüksek Lisans tezi, Hacettepe Üniversitesi Sosyal Bilimler Enstitüsü, 2010), s. 82. 
sınavdan hoşlanmama ve daha az etkili çalışma yetenekleriyle doğrudan ilişkili olduğu tespit edilmiştir.23

Sınav kaygısının tedavisinde psikoterapi ve ilaçla tedavi şeklinde farklı uygulamalar bulunmaktadır. Davranışsal tedaviler, sınav kaygısını bir şartlanmış tepki olarak görmelerinden ötürü kaygıyı azaltmak için özel yöntemlerle şartlanmanın çözülmesi üzerine odaklanmaktadırlar. Ayrıca sınav kaygısı ile başa çıkmada solunum ve gevşeme egzersizleri, spor, meditasyon, sağlıklı beslenme, aşırı vitamin hapı almama, kahve, çay ve sigara gibi heyecan arıtıcı maddelerden uzak durma gibi davranışsal yöntemler de bulunmaktadır. ${ }^{24}$ Bilişsel terapi sınav kaygısı olan bireylerde ki akıl dışı düşünce ve kaygıyı değiştirmeyi amaçlayan bir dizi yaklaşımı ihtiva etmektedir. Bunun için sınavın uyandırdığı duygu ve düşüncelerin farkına vardırma, sonra bu düşüncelerin altında yatan gerçek dışı ve anlamsız olanları belirleme ve sorgulama, son olarak ise gerçekçi olmayan ve kaygıya neden olan bu düşüncelerin yerine gerçekçi alternatifler koyma uygulamaları yapılmaktadır. ${ }^{25}$ Biofeedback (deri iletkenliği, sıcaklık, kalp hızı, solunum gibi) bir ya da daha fazla fizyolojik süreç hakkında anlık ve devamlı bilgi sağlamada aletlerin kullanımı olarak isimlendirilmektedir. Biofeedback yüksek kaygılı bireylere duygusal tepkileri ile ilişkili olan fizyolojik tepkilerini izleme ve değiștirmeyi öğretmektedir. Sınav kaygısı tedavisinde biofeedback tek başına kullanılabildiği gibi diğer tedavi yaklaşımları ile birlikte de kullanılabilmektedir. ${ }^{26}$ Günümüzde kaygı tedavisinde Benzodiazepineslerden Alprazolam, Clonazepam ve Antidepresan türü ilaçlar yaygın olarak kullanılmaktadır. ${ }^{27}$ Kaygı bozukluğu tedavisinde ilaçla tedavi uygulamaları yapılmakla birlikte terapi mi yoksa ilaç tedavisi mi daha iyidir soruna kesin bir cevap vermek zordur. Her iki yöntemin avantajları ve dezavantajları bulunmaktadır. Bundan dolayı kaygı bozukluğu tedavisinde hastanın durumu dikkate alınarak her birey için en iyi olan tedavi şekli belirlenerek uygulanmaktadır.

\section{Kaygl, Din ve Dua}

Din kelimesi sözlükte "ibadet, itaat, boyun eğme, ceza, mükâfat, tutulan ve gidilen yol," gibi anlamlara gelmektedir. ${ }^{28}$ Terim olarak ise din, selim akıl sahiplerine hakikatin gayesini bildiren, onları kendi irade ve seçimleriyle Allah'ın elçilerinin

\footnotetext{
23 Ray Hembree, "Correlates, Causes, Effects, and Treatment of Test Anxiety", Review of Educational Research, 58/1 (1988), 73.

Kurt, Sınav Kaygısını Așmanın Yolları, s. 178.

25 Albert Ellis, Catharine MacLaren, Rational Emotive Behavior Therapy, California: Impact Publishers, 1998, s. 5.

26 Zeidner, Test Anxiety, The State of The Art, s. 351

27 Donna Toufexis - Sayamwong E. Hammack, Anti-Anxiety Drugs, New York: Chelsea House Publishers, 2006 s. 17-48.

28 Râgıb el-Îsfehânî, Müfredat, Kur'an Kavramları Sözlüğü, (çev. Abdulbaki Güneş - Mehmet Yolcu), Çıra Yayınları: İstanbul, 2012, s. 393.
} 
bildirdiği șekilde, iyilik, doğruluk ve kemâle, öbür dünyada kurtuluşa götüren ve Allah tarafından konulmuş ilahi bir kanundur. ${ }^{29}$

Yapılan pek çok araştırmada din/dindarlı̆̆ın pozitif duyguları desteklediği, negatif duygulara karşı koruyucu ve tedavi edici bir rol üstlendiği tespit edilmiştir. ${ }^{30}$ Ciddi sağlık sorunları, ölüme yaklaşma, kaza, bela gibi negatif yaşamsal olaylar bireylerde korku, kaygı, stres, öfke ve depresyon duygularının oluşmasına neden olabilmektedir. Din hayata ve olaylara anlam kazandırarak, bütüncül bir bakış kazandırarak yaşamsal olayların yol açtığı kaygı, stres, depresyon ve öfke duygularına karşı bireyi korunaklı hale getirmektedir. Anlamın olmadığı bir hayat daha fazla kaygı içermektedir. Kaygı ile başa çıkmada olaylara anlam bulmak önemlidir. Logoterapi'nin (Anlam Terapisi) kurucusu Viktor Frankl'a göre hayatta sadece iyi olaylara değil aynı zamanda negatif olaylara anlam bulmak bireyin varlığını sürdürebilmesi ve mutluluğu için gereklidir. Frankl'a göre din insanın hayatına eşsiz anlam ve amaç kazandıran bir olgudur. Ayrıca anlam ihtiyacı bir eser bırakarak, bir insanla etkileşerek veya acıya karşı bir tavır geliştirerek de giderilebilir. ${ }^{31}$

İslam inancına göre insanın başına gelen her şey Allah'ın takdiri ile meydana gelmektedir. Bu inanca sahip olan dindar bir birey olayların arka planında ilahi bir irade olduğunu bildiğinden dolayı negatif yaşamsal olayların zahiri sebeplerine çok fazla takılarak negatif duygu ve davranışlarda tecrübe etmez. Din ve maneviyat bireylere ahlaki ve duygusal destek, iç huzuru, öz güven, cesaret, ümit, bağışlayıcılık, sevgi duygularını geliştirerek kişisel kaygının azaltılmasına yardımcı olmaktadır. Dindarlık arttıkça birey kaygı uyandırıcı negatif yaşamsal olaylarla başa çıkmada daha fazla içsel kaynağa sahip olduğunu düşündüğünden dolayı daha fazla güven sahibi olmaktadır. Din negatif olaylarında pozitif sonuçları olabileceğini öğreterek bireyin hayata ve olaylara daha iyimser açıdan bakabilmesine katkı sağlamaktadır. Aynı zamanda dindar birey Yaratıcının isteklerine uygun bir hayat yaşadığı için Tanrı'nın her zaman kendisi ile olduğu ve sıkıntılarını aşmada yardımcı olacağına inanmakta, dolayısıyla daha fazla güven ve umut içinde olmaktadır. Kaygının bilişsel boyutu olaylara yönelik gerçekçi, rasyonel olmayan düşünceleri içermektedir.

29 Hüsamettin Erdem, Problematik Olarak Din-Felsefe Münasebeti, Konya: Sebat Ofset Matbaacllık, 1997, s. 27.

David B. Larson v.dğr., "Associations between dimensions of religious commitment and mental health reported in the American Journal of Psychiatry and Archives of General Psychiatry: 1978-1989", American Journal of Psychiatry, (1992), 558; David B. Larson - Susan S. Larson, "Spirituality's Potential Relevance to Physical \& Emotional Health: A Brief Review of Quantitative Research", Journal of Psychology \& Theology, 31(2013), 37-51; Marwin W. Acklin - Earl C. Brown - Paul A. Mauger, "The Role of Religious Values in Coping with Cancer", Journal of Religion and Health 22/4 (1983), 330; Sarah Reiland - Dean Lauterbach, "Effects of Trauma And Religiosity on Self-Esteem" Psychological Report, 102 (2008), 779; Necmi Karsl, Mutluluk ve Dindarlık, Kayseri: Kimlik Yayınları, 2018, s. 256; Necmi Karslı, Öfke Kontrolü ve Dindarlık, Kayseri: Kimlik Yayınları, 2018, s. 341; Hasan Kayıklık, Din Psikolojisi, Adana: Karahan Kitabevi, 2011, s. 287.

31 Viktor Frankl, İnsanın Anlam Arayışı, (çev. Selçuk Budak), İstanbul: Öteki Yayınevi, 2007, s. 105,106 . 
İbadetler, camiye devam etme farklı ortamlar sağlayarak yüksek kaygıya yol açan kasvetli düşünce şeklini yok etmektedir.

Bir işin gereğini yerine getirdikten sonra neticeyi Allah'a havale etme anlamına gelen tevekkül sınav kaygısı ile başa çıkmada önemli bir destek işlevi görmektedir. İslam'da dua sözlü ve fiili dua şeklinde iki kısma ayrılmaktadır. Tevekkülde hem sözlü hem de fiili dua bir arada bulunmaktadır. Kur'an'ı Kerim'de "Allah'a tevekkül et, vekil olarak Allah yeter"32, "Kim Allah'a güvenirse 0, ona yeter"33 ayetlerini de kapsayan toplam 34 ayette inanlara sıkıntılar karşısında tevekkül etme tavsiye edilmektedir. Bununla birlikte tevekkül tembellik yapıp, iyi sonuç için Allah'a güvenmek demek değildir. Bir adam Hz. Muhammed'e "Hayvanımı bağlayıp da mı yoksa bağlamadan mı Allah'a tevekkül edeyim?” diye sorduğunda, "Önce bağla, sonra tevekkül et!" 34 buyurmuştur. Bu hadisten de anlaşlacağı üzere İslam'da bir iş için çalışıp gereği getirildikten sonra neticeyi Allah'a havale etme tavsiye edilmektedir.

Şekil, zaman ve mekânsal açıdan sınırlaması olmayan, inanan bireyin Allah'a yakarışı, yalvarışı, Allah'la ilişki kurması ve ondan yardım dilemesi şeklinde tanımlanan duanın, kaygı ve diğer negatif duyguların etkilerinden koruyucu ve tedavi edici gücü bulunmaktadır. ${ }^{35}$ Kur'an-ı Kerim'de "Duanız olmazsa Rabbim size ne diye değer versin ki?"36, "Bana dua edin duanızı kabul edeyim"37, "Rabbinize yalvararak, sessiz ve derinden dua edin"38 ayetlerinde ve Hz. Muhammed'in "dua ibadetin özüdür"39 hadisinde duanın önemi vurgulanmaktadır. Kur'ani bakış açısından bireyi duaya yönelten temel güdüler korku ${ }^{40}$, güçsüzlük ve çaresizlik bilinci $^{41}$ ile dünyevi ${ }^{42}$ ve uhrevi ${ }^{43}$ isteklerdir. ${ }^{44}$ Yaparel'e göre ise duanın altında muhakeme, bağımlılık, dinsel içgüdü, şaşkınlık ve huşu ile hayatın anlamını arama güdüleri yatmaktadır. ${ }^{45}$

Dua çok etkili bir dini psikoterapi yöntemidir. Kaygı bozukluğu ve diğer psikolojik hastalıkların tedavisinde en başta bireyin sorunu kabul etmesi ve bir uzmana başvurarak sorununu açması gereklidir. Ancak bireyler çeşitli nedenlerden ötürü psikolojik sorunlarını paylaşmaktan kaçınabilirler. Oysa dua yoluyla birey kendisinde sorun olarak kabul ettiği ancak ikinci bir insana açmak istemediği

Ahzap 33/3.

Talak 35/3.

Tirmizî, "Kıyâmet", 60.

Hüseyin Peker, Din Psikolojisi, İstanbul: Çamlıca Yayınları, 2011, s. 123.

Furkan 25/77.

Mü'min 40/60.

A'raf 7/55.

Tirmizi, "Kitabu'd-De'avat", 49.

Yunus 10/22,23.

Yunus 10/12; A'raf 7/126.

Fatiha 1/5; el-Bakara 2/126; Ali İmran 3/38; Felak 113/1-5.

Ali İmran 3/194; Şuara, 25/85; el-Bakara 2/201.

Asım Yapıcı, "Güdü ve İçerik Açısından Çocuklarda Dua ve Dualara Yansıyan Sorunlar”, ÇÜİFD, 5/2, (2005), 60; Hasan Kayıklık, Din Psikolojisi, Adana: Karahan Kitabevi, 2011, s. 131.

4 Recep Yaparel, "Dua, Psikolojik Bir Yaklaşım”, Dokuz Eylül Üniversitesi Illahiyat Fakültesi Dergisi, (1995), 9. 
sorunlarını gizli, açık her şeyi bildiğine ve gücünün yettiğine inandığı Tanrı'ya açarak, O’ndan yardım isteyebilir. Böylece birey içine attığı çözümlenmemiş sorununu paylaşmanın neden olduğu psikolojik rahatlamanın yanında sorununun çözümünde Tanrı'nın kendisine yardım edeceğine yönelik güven duyusu tecrübe edebilmektedir. Azhar ve arkadaşları kaygı bozukluğunda dini psikoterapinin etkisini inceledikleri araştırmalarında kaygı bozukluğu olan rastlantısal olarak seçilmiş 62 Müslüman birey deney ve kontrol grubu şeklinde iki gruba ayrılmış, kontrol grubuna geleneksel psikoterapi ve ilaç tedavisi, deney grubuna ise içinde dua ve belli ayetlerin okunmayı içeren dini psikoterapi uygulaması yapılmıştır. Araştırma sonucunda dini psikoterapi uygulaması yapılan hastaların kaygı belirtilerinin geleneksel psikoterapi uygulanan hastalara göre daha hızlı şekilde iyileşme gösterdiği tespit edilmiştir. ${ }^{46}$ Salleh ve arkadaşlarının kaygı bozukluğu olan 165 Malay kökenli Müslüman birey üzerinde yaptıkları araştırmasında da benzer şekilde dini-kültürel psikoterapi uygulanan hastaların standart psikoterapi uygulanan kontrol grubuna nazaran kaygı belirtilerinin daha hızlı azaldığ görülmüştür. ${ }^{47}$ Peki acaba duanın birey üzerindeki etkisi bir plesabo mudur yoksa bireysel tecrübenin ötesinde Tanrısal bir müdahaleyi kapsayan yönü de var mıdır? Harris ve arkadaşlarının koroner bakım ünitesinde tedavi görmekte olan hastalar üzerinde gıyabi duanın etkisini incelemek için yaptıkları araştırmada hastalar deney ve kontrol grubu şeklinde iki gruba ayrılmıștır. Deney grubundaki hastalara kendileri için dua edildiği bildirilmeksizin tanımadıkları kişiler tarafından dört hafta boyunca her gün dualar yapılmıș, kontrol grubundaki hastalara ise sadece standart tedavi prosedürü uygulanmıştır. Araştırma sonucunda habersiz olarak kendilerine gıyabi dua yapılan deney grubundaki hastaların daha fazla iyileşme gösterdikleri tespit edilmiştir. Araştırma duanın standart tıbbi tedaviye çok etkili bir şekilde destek olabileceğini göstermiştir. ${ }^{48}$ Byrd'un araştırmada da Haris ve arkadaşlarının bulgularına benzer şekilde koroner bakım ünitesinde kalan hastalara yönelik yapılan gıyabi duanın iyileștirici etkilere neden olduğu tespit edilmiştir. ${ }^{49}$

Dua ibadetinin yaşamsal sıkıntıların neden olduğu psikolojik gerilimin yatıştırılmasında önemli etkisi olmakla birlikte duanın gücünden istifade edebilme en başta dua ibadetine katılıma bağlıdır. Dindarlar diğer ibadetlere olduğu gibi dua ibadetine de dindar olmayanlardan daha fazla katılmaktadırlar. Albayrak'ın üniversite öğrencileri üzerinde yaptığı araştırmada bireylerini dini tutumları ile dua davranışları arasında güçlü pozitif yönlü ilişki tespit edilmiştir. ${ }^{50}$ Dua genellikle bir pozitif dini başa çıkma aracı olarak kullanılsa da bazı bireyler dua ile istediklerini

\footnotetext{
46 Azhar, M. Z. - Varma, S. L. - Dharap, A. S., "Religious Psychotherapy in Anxiety Disorder Patients." Acta Psychiatrica Scandinavica, 90/1 (1994), 1-3.

47 Salleh Mohd. Razali, Kassim Aminah, Umeed Ali Khan, "Religious-Cultural Psychotherapy in The Management Of Anxiety Patients", Transcultural Psychiatry, 39/1 (2002), 130.

48 William S. Harris, v.dğr., "A Randomized, Controlled Trial of The Effects of Remote, Intercessory Prayer on Outcomes In Patients Admitted To The Coronary Care Unit", Arch Intern Med, 159 (1999), 2273.

49 Randolph C. Byrd, "Positive Therapeutic Effects Of Intercessory Prayer in A Coronary Care Unit Population", Southern Medical Journal , $81 / 7$ (1988), 826.

50 Ahmet Albayrak, Gençlerde Dua Psikolojisi, İstanbul: Düşünce Yayınları, 2013, s. 125.
} 
elde edemediklerinde veya dualarına cevap verilmediğini düşündüklerinde negatif dini başa çıkma yaparak dinden uzaklaşabilmektedirler.

Dindarlık ve kaygı ilişkisi konusunda yapılan araştırmaların bazılarında dindarlık ile kaygı arasında pozitif, bazılarında negatif yönlü ilişki görülürken bazı araştırmalarda iki olgu arasında anlamlı bir ilişki görülmemiştir. Örneğin Yıldız’ın ve Kımter ile Köftegül'ün araştırmalarında dindarların daha fazla ölüm kaygısı tecrübe ettikleri görülürken, Karaca'nın araştırmasında dindarlık arttıkça ölüm kaygısının azaldığı tespit edilmiştir. ${ }^{51}$ Ayten'in araştırmasında da dindarlığın ölümü kabullenmeyi kolaylaştırdığı ve ölüm kaygısını azalttığı tespit edilmiştir. ${ }^{52}$ Yapıcı ile Kayıklık'ın araştırmasında dini eğilim ile kaygı arasında negatif yönlü anlamlılık seviyesine ulaşmayan ilişki bulunmuştur. ${ }^{53}$ Kartopu'nun araştırmasında da dindarlık ile süreli kaygı arasında anlamlı bir ilişki görülmemiştir.54

\section{Yöntem}

\section{1. Ölçme Araçları}

\subsubsection{Kişisel Bilgi Anketi}

Araştırma anketinin kişisel bilgi kısmında yaş, cinsiyet, sosyo-ekonomik durum, eğitim durumu ve sigara kullanımı ile ilgili ifadeler bulunmaktadır.

\subsubsection{Sinav Kaygısı Envanteri}

Araştırmada, sınav kaygısını ölçmek için, Spielberger tarafından geliştirilen ve Türkçe'ye uyarlaması Necla Öner tarafından yapılan Sınav Kaygısı Envanteri kullanılmıştır. Toplamda 20 sorudan oluşan ölçekten alınabilecek en düşük tüm test puanı 20, en yüksek tüm test puanı ise 80 'dir. Ölçeğin sadece ilk maddesi ters şekilde puanlanmaktadır. Ölçekten elde edilen puanların yüksekliği sınav kaygısının yüksekliğini göstermektedir. Ölçeğin test tekrar test güvenirliliğini yapılan farklı uygulamalarda, Pearson Momentler Çarpımı korelasyon katsayıları .70 ile .90 arasında bulunmuştur. Kuder-Richardson güvenirliği tüm test için .46’nın, alt testler için .43'ün altına düşmemiştir. Ölçeğin Türkçe formunun standart hatası örneklemin eğitim düzeyine göre 3.49 ile 4.63 arasında değişmektedir. Ölçeğin ölçüt-bağımlı geçerliliği ile ilgili olarak Sınav Kaygısı Envanteri puanlarının Sürekli Kaygı Ölçeği ve

51 Murat Yıldız, "Dinî Hayat İle Ölüm Kaygısı Arasındaki İlişki Zerine Bir Araştırma”, (doktora tezi, Dokuz Eylül Üniversitesi Sosyal Bilimler Enstitüsü, 1998), s. 108; Nurten Kımter, Özlem Köftegül, "Ölüm Kaygısı İle Dindarlık Arasındaki İlişki Üzerine Bir İnceleme", Sakarya Üniversitesi Illahiyat Fakültesi Dergisi, (2017), 55; Faruk Karaca, Ölüm Psikolojisi, İstanbul: Beyan Yayınları, s. 350.

52 Ali Ayten, "Üniversite Öğrencilerinde Ölüm Kaygısı: Türk ve Ürdünlü Öğrenciler Üzerine Karşılaștırmalı Bir Araștırma”, Din Bilimleri Akademik Araştırma Dergisi, $9 / 4$ (2009), 85.

53 Asım Yapıcı, Hasan Kayıklık, "Ruh Sağlığı Bağlamında Dindarlığın Özsaygı ve Kaygı ile İlişkisi: Çukurova Üniversitesi Örneği”, Değerler Eğitimi Dergisi, 3 /9 (2005), 191.

54 Saffet Kartopu, "Lise Öğrenci Ve Öğretmenlerinin Durumluk Ve Sürekli Kaygi Düzeylerinin Bazı Değişkenler Açısından İncelenmesi (Kahramanmaraş Örneği)”, Fırat Üniversitesi İlahiyat Fakültesi Dergisi, 17/2 (2012), 164. 
sınav koşullarında Durumluk Kaygı Ölçeği Puanları ile korelasyonları .39 ile .70 arasında değiştiği görülmüştür. Yapı geçerliliği ilgili olarak Öz Kavramı Ölçeği ile Sınav Kaygısı Envanteri puanları arasında orta düzeyde ve olumsuz (-.31 ile-.56) Minnesota Danışma Envanteri ile sınav kaygısı puanları arasında orta düzeyde ve olumlu (.60 ile .22) ilişki saptanmıştır. 55

\subsubsection{Dini Şuur Ölçeği}

Seyhan tarafından Anadolu kültüründeki dini hayat ve maneviyatı ölçmek için geliştirilmiş olan Dini Şuur Ölçeği toplamda 21 maddeden oluşmaktadır. Ölçek Müslüman bireylerin inandıkları dini değerleri hayatlarına ne kadar yansıttıkları ve dini bilinçlilik ve farkındalıklarını ölçmek amacı taşımaktadır. Ölçeği'nin puanlamasında likert tipi beşli bir derecelendirme kullanılmıştır. Buna göre ölçekten en az 21 en çok ise 105 puan alınabilir. Geliştirilme sürecinde test-tekrar test yöntemi kullanılan ölçek aynı gruba iki defa uygulanmış ve açımlayıcı faktör analizine yapılmıştır. Açımlayıcı faktör analizinde ölçeğin "Değer", "Bilinç", ve "Davranış" şeklinde üç alt boyuta sahip olduğu görülmüştür. Ölçeğin açlkladığı toplam varyans \%54,362 olarak bulunmuştur. Cronbach's Alfa kat sayısı ise .928'dir. Ölçek üzerinde uygulanan doğrulayıcı faktör analizinde Ki-Kare değerinin ( $\mathrm{CMIN}=351,75 ; \mathrm{N}=225 ; \mathrm{sd}=184 ; \mathrm{p}=0,000$ ) anlamlı olduğu, uyum indeks değerleri ise RMSEA=,056, CFI =,97; IFI=,922; GFI =,872; SMRM $=, 051 ; \quad$ TLI $=, 910$ olarak bulunmuştur. Ölçeği'nin açımlayıcı ve doğrulayıcı faktör analizi değerlerinin istatiksel açıdan kabul edilebilir düzeyde olduğu görülmüştür. Bu verilere göre ölçek teorik ve istatiksel açıdan kullanılışlıdır. ${ }^{56}$

\subsection{4. İçsel Dini Motivasyon Ölçeği}

Dean Hoge tarafından geliştirilen ve Türkçe'ye uyarlaması Karaca tarafından yapılan İçsel Dini Motivasyon Ölçeği, 10 maddeden oluşmaktadır. Ölçeğinin 7 maddesi olumlu 3 madde ise olumsuz cümle yapısında kurulmuştur. Ölçekte 5 dereceli likert formatı kullanılarak 1'den 5'e kadar, zayıftan kuvvetliye doğru puanlama yapılan ölçekten en düşük 10 en yüksek 50 puan alınabilir. Ölçeğin Türkçe' formunun güvenirlilik analizlerinde, homojenlik endeks ve yarıya bölme teknikleri kullanılmıştır. Ölçeğin geçerliği faktör analizi ve iç tutarlılık teknikleri kullanılarak hesaplanmıştır. Ölçek maddeleri yarıya bölme tekniği ile analiz edilmiş ve iki yarım ölçek arasındaki korelasyon katsayısı .76 olarak bulunmuştur. Ölçeğin içsel tutarlılık ölçütü olan Cronbach's Alfa katsayısı .84 olarak bulunmuştur. Ölçeğin geçerliliğinin tespiti için uygulana faktör analizi sonucunda biri hariç ölçek maddelerinin tamamının aynı faktörde toplandı̆̆ı görülmüştür. Ölçek maddelerinin

$55 \quad$ Necla Öner, Türkiye'de Kullanılan Psikolojik Testlerden Örnekler, İstanbul: Boğaziçi Üniversitesi Yayınları, 2012, s. 770,773; Necla Öner, Sınav Kaygısı Envanteri El Kitabı, İstanbul: Yüksek Öğrenimde Rehberliği Tanıtma ve Rehber Yetiştirme Vakfı Yayını, 1990, s. 1,2; Pedagog Sitesi, "Sınav Kaygısı ile Nasıl Başa Çılkılır”, http://pedagogsitesi.com/sinav-kaygisi-nedir-nasil-basacikilir/ (Erişim: 26 Kasım 2018)

56 Beyazıt Yaşar Seyhan, "Dini Şuur Ölçeği: Geçerlik ve Güvenirlik Çalıșması", EKEV Akademi Dergisi, 19/61 (2015), 399-406. 
iç tutarlılığını belirlemek için korelasyon katsayıları hesaplanmış ve ölçek maddelerinin tamamının aynı yönde ayrıştıkları saptanmıștır. ${ }^{57}$

\subsection{Problem}

Araştırmanın temel problemi özellikle genç bireylerde yoğun olarak görülen sınav kaygısı ile dindarlık ve dua ilişkisini tespit etmektedir. Ayrıca araştırmamın alt problemleri örneklemin yaş, cinsiyet, sosyo-ekonomik durum ve sigara kullanımı ile dindarlık ve sınav kaygısı arasındaki ilişkileri tespit etmektir. Bu bağlamda demografik değişkenler ve dindarlık alt boyutları ve toplam dindarlık düzeyleri bağımsız değişkenler olarak alınmış, bu etkenlerin sınav kaygısı üzerindeki etkileri incelenmiştir.

\subsection{Hipotezler}

Araştırma hipotezlerimiz iki kısma ayrılmaktadır. Birinci kısımdaki hipotezlerimiz, demografik değişkenler ile dindarlık ve sınav kaygısı arasındaki ilişkiler üzerine odaklanırken, ikinci kısım hipotezlerimiz dindarlık ile sınav kaygısı arasındaki ilişkiler üzerinde durmaktadır.

Birinci kısım hipotezlerimiz şunlardır:

A1. Kadınların sınav kaygısı erkeklerinkinden daha yüksektir.

A2. Kadınların dini şuuru erkeklerinkinden daha yüksektir.

A3. Sosyo-ekonomik düzey yükseldikçe içsel dini motivasyon ve dini şuur azalır.

A4. İçsel dini motivasyon ve dini şuur arttıkça sigara kullanımı azalır.

İkinci kısım hipotezlerimiz ise şunlardır:

B1. Dini şuur, dini bilinç ve dini davranışa arttıkça sınav kaygısı azalır.

B2. Dua sinav kaygısının dindirilmesinde etkilidir.

B3. Dua ve besmele ile sınava başlamak sınav başarısını olumlu etkiler.

B4. "Dua sinav kaygısını yenmede her zaman yardımcı olur" diyenlerin sinav kaygısı bazen ve sik sik diyenlerinkinden daha düşük olur.

B5. "Besmele ve dua ile başladığım sınavlarda her zaman daha başarılı olurum" diyenlerin sınav kaygısı bazen ve sık sık diyenlerinkinden daha düşük olur.

\subsection{Evren ve Örneklem}

Araştırmanın örneklemi 2017-2018 eğitim-öğretim yllında Trabzon İl Merkezinde Millî Eğitim Bakanlı̆̆ı'na bağlı muhtelif orta öğretim kurumlarında öğrenim görmekte olan öğrenciler ile Karadeniz Teknik Üniversitesi'nde İlahiyat Fakültesinde öğrenim görmekte olan toplam 555 genç bireyden oluşmaktadır.

57 Faruk Karaca, "Din Psikolojisinde Metot Sorunu ve Bir Dindarlık Ölçeğinin Türk Toplumuna Standardizasyonu”, EKEV Akademi Dergisi, 3/1 (2001), 196-199. 


\subsection{Sinırlılıklar}

Araştırmanın temel sinırlılıkları şunlardır.

1. Örneklemin çoğunluğu üniversite ve lise öğrenimi görmekte olan benzer yaş, meslek ve ekonomik seviyedeki sahip bireylerden oluştuğu ve örneklem sayısı (555) sınırlı olduğu için araştırmadan elde edilen sonuçlar tüm yaş gruplarına genellenemez. Aynı konuda yapılacak diğer araştırmalarda farklı sonuçlar elde edilebilir.

2. Çalışma aynı grubun belli süre aralıklarıyla takip edildiği araştırma türü olan boylamsal araştırma değil aynı anda benzer özelliklere sahip bireyler üzerinde uygulanan kesitsel bir araştırmadır. Bu nedenle sonuçlar verilerin elde edildiği mekân ve zaman açısından değerlendirilmelidir.

3. Araştırma verileri sınav kaygısı ölçeği ve dindarlığını ölçme için kullanılan araçların geçerlilik ve güvenirlik düzeyi ile sınırlıdır. Ayrıca araştırma örneklemin ölçek sorularını anlama düzeyi ile gerçek kanaatlerini ankete yansıtıp yansıtmama durumu ile sinırlıdır.

\subsection{Verilerin Analizi}

Araştırmada kullanılan anket verilerinin bilgisayara girilmesi ve istatistik analizinde SPSS (v23) programı kullanılmıștır. İșlem aşamaları olarak ise öncelikle örneklemin demografik değişkenlere göre yüzdeler hesaplanmış, daha sonra demografik değişkenlerle dindarlık ve sınav kaygısı arasındaki ilişkilere bakılmış, en sonunda ise dindarlık ile sınav kaygısı arasındaki ilişkiler incelenmiştir. Verilerin istatiksel analizi için frekans, t-testi, tek yönlü anova, korelasyon, ki-kare ve regresyon analizi işlemleri yapılmıștır. Anlamlı olan veya önemli görülen ilişkilere yer verilmiştir.

\section{Bulgular}

\subsection{Demografik Değişkenlere Göre Örneklem Grubunun Özellikleri}

Yaş: Örneklemin 200’ü kişi (\%36) 16-20 yaş grubunda, 355'i ise (\%64) 2145 yaş grubunda yer almaktadır.

Cinsiyet: Örneklemin 367'si (\%66,1) kadın, 188'i (\%33,9) ise erkektir.

Eğitim Durumu: Örneklemin 136'sı $(\% 24,5)$ lise, 419’u ise $(\% 75,5)$ üniversite öğrencisidir.

Sosyo-Ekonomik Durum: Örneklemden 46 kişinin (\%8,3) sosyo-ekonomik durumu düşük, 486 kişinin $(\% 87,6)$ orta, 23 'ünün $(4.1)$ ise sosyo-ekonomik durumu yüksek seviyededir.

Sigara Kullanımı: Örneklemin 50'si (\%9) sık sık, 29’u (\%5,2) ara sıra, 43’ü $(\% 7,7)$ nadiren sigara kullanırken, 433’ü $(\% 78)$ hiç sigara kullanmamaktadır. 


\subsection{Demografik Değişkenlere Göre Sınav Kaygısı ve Dindarlık Düzeyleri}

Tablo 1. Demografik Değişkenler ile Sınav Kaygısı ve Dindarlık Arasındaki Korelasyonlar

\begin{tabular}{lccccc}
\hline & Cinsiyet & Ekonomi & Sigara & Sağlık & Kişilik \\
\hline Sınav Kaygısı & $-.190^{* *}$ & -.030 & .081 & -.061 & -.071 \\
İçsel Dini Motivasyon & -.070 & .018 & $.232^{* *}$ & .004 & .060 \\
Dini Şuur & $-.143^{* *}$ & .008 & $.277^{* *}$ & .045 & .012 \\
\hline \multicolumn{2}{c}{ (Not: ${ }^{* *}$. Cift yıldızlı olanlar 0,01 düzeyinde anlamlıdır) }
\end{tabular}

Tablo 1'de görüldüğü gibi araştırmamıza katılan örneklemin sınav kaygısı ile cinsiyet $(\mathrm{r}=-.190, \mathrm{p}<.01)$, İçsel Dini Motivasyon ile sigara kullanımı $(\mathrm{r}=.232, \mathrm{p}<.01)$ ve Dini Şuur ile cinsiyet $(\mathrm{r}=-.143, \mathrm{p}<.01)$ ve sigara kullanımı arasındaki $(\mathrm{r}=.232$, $\mathrm{p}<.01)$ korelasyonlar istatiksel olarak anlamlılık derecesine ulaşmıştır.

Tablo 2. Cinsiyete Göre Sınav Kaygısı Düzeyleri

\begin{tabular}{|c|c|c|c|c|c|}
\hline & Cinsiyet & $\mathbf{N}$ & $\%$ & $\overline{\mathbf{X}}$ & sS \\
\hline Sinav & Kadın & 367 & 66.1 & 43.21 & 12.11 \\
\hline \multirow[t]{2}{*}{ Kaygısı } & Erkek & 188 & 33.9 & 38.48 & 10.40 \\
\hline & & 4.783 & $\mathrm{df}=553$ & $\mathrm{p}=.000$ & \\
\hline
\end{tabular}

Tablo 2'de ki verilere göre bayanların sınav kaygısı ölçeğinden aldıkları ortalama skor $\overline{\mathrm{X}}=43.21$ iken, erkeklerin aynı ölçekten aldıkları ortalama skor $\overline{\mathrm{X}}=38.48$ 'dir. Uygulamış olduğumuz T-Testi sonucunda bayanların sınav kaygısı düzeyinin erkeklerinkinden anlamlı bir şekilde daha yüksek olduğu tespit edilmiştir (t0.05:553=4.783, p=.000, p<.05). Bununla birlikte cinsiyet ile sinav kaygisı arasındaki bağımlılığı tespit için yaptığımız Ki-Kare analizinde bayanların \%67,7' sinin ( $n=109)$ sınav kaygısı yüksek çıkarken, erkeklerden sınav kaygısı yüksek olanların oranı \%41,8 (n=28) olarak tespit edilmiştir. Ki-Kare analizine göre de cinsiyet ile sınav kaygısı arasında bir bağımlılık bulunmaktadır $(X=13.245, d f=1$ $\mathrm{p}=.000, \mathrm{p}<.05)$.

Tablo 3. Cinsiyete Göre Dini Şuur Düzeyleri

\begin{tabular}{|c|c|c|c|c|c|}
\hline \multirow{4}{*}{ Dini Şuur } & Cinsiyet & $\mathbf{N}$ & $\%$ & $\overline{\mathbf{X}}$ & SS \\
\hline & Kadın & 367 & 66.1 & 83.60 & 10.83 \\
\hline & Erkek & 188 & 33.9 & 79.94 & 13.97 \\
\hline & & $t=3.140$ & $\mathrm{df}=553$ & $\mathrm{p}=.002$ & \\
\hline
\end{tabular}

Tablo 3'te ki verilere göre kadınların dini şuur ölçeğinden aldıkları ortalama skor $\mathrm{X}=83.60$ iken, erkeklerin aynı ölçekten aldıkları ortalama skor $\mathrm{X}=79.94$ 'tür. Uygulamış olduğumuz T-Testi sonucunda kadınların dini şuur düzeyinin erkeklerinkinden anlamlı bir şekilde daha yüksek olduğu tespit edilmiştir (t0.05:553=3.140, p=.002, $\mathrm{p}<.05$ ).

Tablo 4. Sosyo-Ekonomik Duruma Göre İçsel Dini Motivasyon ve Dini Şuur Düzeyleri 


\begin{tabular}{|c|c|c|c|c|c|c|c|}
\hline \multirow{5}{*}{$\begin{array}{l}\text { İçsel Dini } \\
\text { Motivasyon }\end{array}$} & \multicolumn{2}{|c|}{$\begin{array}{c}\text { Sosyo- } \\
\text { Ekonomik } \\
\text { Durum } \\
\end{array}$} & \multirow{2}{*}{$\begin{array}{l}\mathbf{N} \\
46\end{array}$} & \multirow{2}{*}{$\begin{array}{c}\% \\
8.3\end{array}$} & \multirow{2}{*}{$\begin{array}{c}\overline{\mathbf{X}} \\
39.43\end{array}$} & \multirow{2}{*}{$\begin{array}{c}\text { SS } \\
7.85\end{array}$} & \multirow{2}{*}{$\begin{array}{l}\begin{array}{l}\text { Tukey } \\
\text { HSD }\end{array} \\
1 / 2\end{array}$} \\
\hline & 1 & Düşük & & & & & \\
\hline & 2 & Orta & 486 & 87.6 & 41.36 & 6.09 & \\
\hline & 3 & Üst & 23 & 4.1 & 38.73 & 8.72 & \\
\hline & & Toplam & 555 & 100 & 41.09 & 6.40 & \\
\hline \multirow{6}{*}{ Dini Şuur } & & $\mathrm{F}_{(2.55}$ & 3.575 & $p=.029$ & $\mathrm{p}<.05$ & & \\
\hline & 1 & Düşük & 46 & 8.3 & 79.15 & 14.66 & $2 / 3$ \\
\hline & 2 & Orta & 486 & 87.6 & 82.93 & 11.42 & \\
\hline & 3 & Üst & 23 & 4.1 & 76.78 & 17.71 & \\
\hline & & Toplam & 555 & 100 & 82.36 & 12.10 & \\
\hline & \multicolumn{3}{|c|}{$F_{(2.552)}=4.667$} & $\mathrm{p}=.010$ & $\mathrm{p}<.05$ & & \\
\hline
\end{tabular}

Tablo 4'te ki verilere göre sosyo-ekonomik durumu düşük olanların içsel dini motivasyon ortalaması $\overline{\mathrm{X}}=39.43$ iken, (orta $=\overline{\mathrm{X}}=41.36$ ), sosyo ekonomik durumu üst seviyede olan örneklemin içsel dini motivasyon skoru ise $X=38.73$ 'tür. Tek yönlü varyans analizinde (Anova) içsel dini motivasyon ile sosyo-ekonomik durum arasında anlamlı bir ilişki tespit edilmiştir ( $\mathrm{p}=.029 \mathrm{p}<.05)$. Buna göre en düşük içsel dini motivasyon ortalaması sosyo-ekonomik seviyesi yüksek olanlarda en yüksek içsel dini motivasyon skoru ise orta seviyede ekonomik duruma sahip olanlarda olduğu görülmüştür. Sosyo-ekonomik duruma göre dini şuur düzeyine gelince, sosyo-ekonomik durumu düşük olanları dini şuur ortalama skoru $\overline{\mathrm{X}}=79.15$, (orta=82.93), sosyo-ekonomik durumu yüksek olanların dini şuur ortalaması ise $\bar{X}=76.78$ 'dir. Tek yönlü varyans analizinde (Anova) örneklemin sosyo-ekonomik durumu ile dini şuur düzeyi arasında anlamlı bir farklılaşma tespit edilmiştir $\left(F_{(2.552)}=4.667 \mathrm{p}=.010 \mathrm{p}<.05\right)$. Post Hoc (Tukey HSD) analizi ise bu durumun sosyoekonomik durumu orta ve üst olanlar arasındaki farklılaşmadan kaynaklandığını göstermiştir.

Tablo 5. Sigara Kullanımına Göre İçsel Dini Motivasyon ve Dini Şuur Düzeyleri

\begin{tabular}{|c|c|c|c|c|c|c|c|}
\hline \multirow{6}{*}{$\begin{array}{l}\text { İcsel Dini } \\
\text { Motivasyon }\end{array}$} & \multicolumn{2}{|c|}{ Sigara Kullanımı } & \multirow{2}{*}{$\begin{array}{c}\mathbf{N} \\
50\end{array}$} & \multirow{2}{*}{$\frac{\%}{9}$} & \multirow{2}{*}{$\frac{\overline{\mathbf{X}}}{37.50}$} & \multirow{2}{*}{$\frac{\text { ss }}{8.65}$} & \multirow{2}{*}{$\frac{\text { Tamhane }}{1 / 4}$} \\
\hline & 1 & Sık sık & & & & & \\
\hline & 2 & Ara sira & 29 & 5.2 & 38.86 & 7.49 & $3 / 4$ \\
\hline & 3 & Nadiren & 43 & 7.7 & 38.55 & 6.58 & \\
\hline & 4 & Hiçbir zaman & 433 & 78 & 41.91 & 5.75 & \\
\hline & & Toplam & 555 & 100 & 41.09 & 6.40 & \\
\hline & \multicolumn{6}{|c|}{$\mathrm{F}_{(3.551)}=11.687 \mathrm{p}=.000 \mathrm{p}<.05$} & \\
\hline \multirow{6}{*}{ Dini Şuur } & 1 & Sık sık & 50 & 9 & 73.76 & 15.60 & $1 / 4$ \\
\hline & 2 & Ara sira & 29 & 5.2 & 78.13 & 12.90 & $3 / 4$ \\
\hline & 3 & Nadiren & 43 & 7.7 & 77.27 & 12.40 & \\
\hline & 4 & Hiçbir zaman & 433 & 78 & 84.15 & 10.91 & \\
\hline & & Toplam & 555 & 100 & 82.36 & 12.10 & \\
\hline & \multicolumn{6}{|c|}{$\mathrm{F}_{(3.551)}=16.551 \mathrm{p}=.000 \mathrm{p}<.05$} & \\
\hline
\end{tabular}


Tablo 5'teki verilere göre sık sık sigara kullananların içsel dini motivasyon ortalama skoru $X=37.50$ iken (ara sıra $=X=38.86$, nadiren $=X=38.55$ ), hiç sigara kullanmayanların içsel dini motivasyon skoru ise $X=41.91$ 'dir. Sigara kullanımına göre dini şuur düzeylerine gelince sık sık sigara kullananların dini şuur ortalama skoru $X=73.76$ iken (ara sıra $=X=78.13$, nadiren $=\bar{X}=77.27$ ), hiç sigara kullanmayanların dini şuur skoru ise $\bar{X}=84.15$ 'tir. Tek yönlü varyans analizinde (Anova) örneklemin sigara kullanımı ile içsel dini motivasyon ( $F=11.687 \mathrm{p}=.000 \mathrm{p}$ $<.05)$, dini şuur ( $\mathrm{F}=16.551 \mathrm{p}=.000 \mathrm{p}<.05)$ düzeyleri arasında anlamlı farklılaşmalar tespit edilmiştir. Post Hoc (Tamhane) analizi ise bu durumun sık sık sigara kullananlar ile hiç sigara kullanmayanlar ve nadiren sigara kullananlar ile hiç sigara kullanmayanlar arasındaki farklılaşmadan kaynaklandığını göstermiştir.

Araştırmada demografik değişkenlerden yaş, eğitim durumu, sosyoekonomik durum, sigara kullanımı ve sağlık durumu ile sınav kaygısı arasında anlamlı bir ilişki görülmediğinden dolayı bu konudaki bulgulara yer verilmemiştir.

\subsection{Dindarlık ve Sınav Kaygısına İlişkin Bulgular}

Tablo 6. Dini Şuur ve Alt boyutları ile Sınav Kaygısı Arasındaki Korelasyonlar

\begin{tabular}{lccc}
\hline & Dini Şuur & Dini Bilinç & Dini Davranış \\
\hline Sınav Kaygısı & $.110^{* *}$ & $.133^{* *}$ & $.112^{* *}$ \\
\hline (Not: **. Çift yıldızlı olanlar 0,01 düzeyinde anlamlıdır) &
\end{tabular}

Tablo 6'da görüldüğü gibi örneklemin sınav kaygısı ile dini şuur ( $\mathrm{r}=.110$, $\mathrm{p}<.01)$, dini bilinç $(\mathrm{r}=.133, \mathrm{p}<.01)$, dini davranıș $(\mathrm{r}=.112, \mathrm{p}<.01)$ düzeyleri arasındaki korelasyonlar istatiksel olarak anlamlılık derecesine ulaşmıştır. İçsel dini motivasyon ve sınav kaygısı ilişkisi konusunda yapılan analizlerde içsel dini motivasyonu yüksek olan örneklemin sınav kaygısı düzeylerinin içsel dini motivasyonu düşük olanlarınkinden daha yüksek olduğu görülmüş olmakla birlikte gruplar arasında istatiksel olarak anlamlı bir farklılık oluşmamıştır (t0.05:207=$1.345, \mathrm{p}=.180, \mathrm{p}>.05$ ).

Tablo 7. Dini Şuur Durumuna Göre Sınav Kaygısı Düzeyleri

\begin{tabular}{|c|c|c|c|c|}
\hline & Dini Şuur & $\mathbf{N}$ & $\overline{\mathbf{X}}$ & SS \\
\hline Sinav & Düşük & 74 & 39.48 & 11.64 \\
\hline \multirow[t]{2}{*}{ Kaygısı } & Yüksek & 89 & 43.47 & 11.93 \\
\hline & & & 161 & \\
\hline
\end{tabular}

Tablo 7'de görüldüğü gibi dini şuur düzeyi düşük olanların sınav kaygısı ortalama skoru $\bar{X}=39.48$ iken, dini şuur düzeyi yüksek olanlarınki ise $\bar{X}=43.47$ 'dir. Uygulamış olduğumuz T-Testi sonucunda dini şuur düzeyi yüksek olanların sınav kaygısı düzeylerinin dini şuuru düşük olanlarınkinden anlamlı bir şekilde daha yüksek olduğu tespit edilmiştir (t0.05:161=-2.146, p=.033, p<.05). Dini şuur ile sinav kaygısı arasındaki bağımlılı̆̆ı tespit için ki-kare analizi yaptığımızda ise sınav kaygısı düşük olanların \%40,7'sinin (n=11) dini şuur düzeyinin yüksek, \%59,3'ünün (n=16) 
ise dini şuur düzeyinin düşük olduğu, sınav kaygısı yüksek olanların \%70'inin $(n=28)$ dini şuur düzeyinin yüksek, \%30'unun $(n=12)$ ise dini şuur düzeyinin düşük olduğu görülmüştür. Sonuç olarak ki-kare analizine göre dini şuur ile kuruntu arasında anlamlı bir bağımlılık bulunmaktadır ( $X=5.673, \mathrm{df}=1, \mathrm{p}=.017, \mathrm{p}>.05)$.

Tablo 8. Dini Şuur ve Sınav Kaygısı Arasındaki Regresyon Analizi

\begin{tabular}{ccccc}
\hline \multirow{2}{*}{ Dini Şuur } & $\boldsymbol{\beta}$ & $\mathbf{t}$ & $\mathbf{p}$ & $\mathbf{R}^{\mathbf{2}}$ \\
\cline { 2 - 5 } & .291 & 2.452 & .017 & .085 \\
\hline
\end{tabular}

Tablo 8'de dini şuur açısından sınav kaygısını açılklamak için uygulanan regresyon analizi sonuçları gösterilmektedir. Analizde dini şuur bağımsız değişken, sınav kaygısı ise bağımlı değișken olarak ele alınmıștır. Regresyon analizi sonucunda dini şuurun sınav kaygısını \%8,5 oranında açıkladığı görülmüştür $(\beta=.291, p<.05)$. Buna göre örneklemin dini şuur düzeyi arttıkça sınav kaygısı da artacaktır.

Tablo 9. Dini Bilinç Durumuna Göre Sınav Kaygısı Düzeyleri

\begin{tabular}{clccc}
\hline \multirow{3}{*}{ Sınav } & Dini Bilinç & $\mathbf{N}$ & $\overline{\mathbf{X}}$ & ss \\
\cline { 2 - 5 } Kaygısı & Düşük & 89 & 39.73 & 12.26 \\
& Yüksek & 117 & 43.63 & 11.68 \\
\cline { 2 - 5 } & \multicolumn{1}{c}{$\mathrm{t}=-2.324$} & $\mathrm{df}=204$ & $\mathrm{p}=.021$ \\
\hline
\end{tabular}

Tablo 9'da görüldüğü gibi Dini Şuur Ölçeği'nin dini bilinç alt boyutundan düşük puan alan örneklemin sınav kaygısı skoru $\bar{X}=39.73$ iken, dini bilinç puanı yüksek olanların sınav kaygısı skoru ise $\overline{\mathrm{X}}=43.63$ 'tür. Uygulamış olduğumuz T-Testi sonucunda dini bilinç düzeyi yüksek olanların sınav kaygısı düzeylerinin dini bilinci düşük olanlarınkinden anlamlı derecede daha yüksek olduğu tespit edilmiştir (t0.05:204=-2.324, $\mathrm{p}=.021, \mathrm{p}<.05$ ).

Tablo 10. Dini Davranış Durumuna Göre Sınav Kaygısı Düzeyleri

\begin{tabular}{clccc}
\hline \multirow{3}{*}{ Sinav } & Dini Davranış & $\mathbf{N}$ & $\overline{\mathbf{X}}$ & ss \\
\cline { 2 - 5 } Kaygısı & Düşük & 95 & 38.40 & 11.16 \\
& Yüksek & 113 & 42.38 & 12.32 \\
\cline { 2 - 5 } & \multicolumn{1}{c}{$\mathrm{t}=-2.422$} & $\mathrm{df}=206$ & $\mathrm{p}=.016$ \\
\hline
\end{tabular}

Tablo 10'da görüldüğü gibi Dini Şuur Ölçeği'nin dini davranış alt boyutundan düşük puan alan örneklemin sınav kaygısı skoru $\bar{X}=38.40$ iken, dini davranış puanı yüksek olanların sınav kaygısı skoru ise $\overline{\mathrm{X}}=42.38$ 'dir. Uygulamış olduğumuz T-Testi sonucunda dini davranış düzeyi yüksek olanların sınav kaygısı düzeylerinin dini davranışı düşük olanlarınkinden anlamlı derecede daha yüksek olduğu tespit edilmiştir (t0.05:206=-2.422, p=.016, p<.05). Araştırmamızda örneklemin Dini Şuur Ölçeği'nin Dini Değer alt boyutu ile Sınav Kaygısı Ölçeği toplamı ve alt boyutları arasında anlamlı bir ilişki bulunmamıştır. 
Araştırmada dua etme davranışı ile sınav kaygısı ilişkisini tespit için örneklemimize besmele ve dua etme tutumlarına yönelik iki adet sorulmuştur. Așağıda bu sorulara verilen cevapların yüzdelikleri ve sınav kaygısı ile ilişkilerine yer verilmiştir.

"Dua sinav kaygisı ve stresini yenmede bana yardımcı olur" ifadesine örneklemimizin 36'sı $(\% 6,5)$ hiçbir zaman, 142'si $(\% 25,6)$ bazen, 149'u $(\% 26,8)$ sık sık, 228'i $(\% 41,1)$ her zaman şeklinde cevap vermiştir. Bu veriler incelendiğinde örneklemin \%67,9'u (sık sık ve her zaman) duanın sınav kaygısını yenmede kendilerine yardımcı olduğunu \%25,6'sı duanın bazen işe yaradığını, \%6,5'i ise duanın sınav kaygısı ve stresini yenmede kendilerine yardımcı olmadığını ifade etmişlerdir. Sonuç olarak örneklemimizin çoğunluğuna göre dua sınav kaygısı ve stresini yenmede yardımcı olmaktadır.

"Besmele ve dua ile başladığım sınavlarda daha başarılı olurum" ifadesine örneklemimizin 52'si $(\% 9,4)$ hiçbir zaman, 243'ü $(\% 43,8)$ bazen, 134'ü $(\% 24,1)$ sık sık ve 126 'sı $(\% 22,7)$ ise her zaman şeklinde cevap vermiştir. Bu verilere göre besmele ve dua ile başlanılan sınavlarda örneklemimizin \%46,8'i (sık sık ve her zaman) başarılı sonuç elde ettiğini ifade ederken örneklemimizin \%43,8'i dua ve besmele ile başladıkları sınavlarda bazen başarılı olduklarını ifade etmişler. Örneklemin sadece \%9,4'ü dua ve besmele ile başlanılan sınavlarda hiçbir zaman başarılı olmadıklarını ifade etmiştir. Bu veriler değerlendirildiğinde dua ve besmele davranışının sınav kaygısının dindirilmesine yardım etmesinin yanında öğrencinin sınav başarısı üzerinde de olumlu etkisi olduğu görülmektedir.

Tablo 11. Dua ile Sınav Kaygısını Yenme Tutumuna Göre Sınav Kaygısı Düzeyleri

\begin{tabular}{|c|c|c|c|c|c|c|c|}
\hline \multirow{7}{*}{ 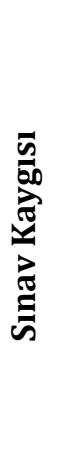 } & \multicolumn{2}{|r|}{$\begin{array}{c}\text { Dua sınav } \\
\text { kaygısını } \\
\text { yenmede bana } \\
\text { yardımcı olur }\end{array}$} & $\mathbf{N}$ & $\%$ & $\overline{\mathbf{X}}$ & sS & $\begin{array}{c}\text { Tukey } \\
\text { HSD }\end{array}$ \\
\hline & 1 & Hiçbir zaman & 36 & 6.5 & 35.58 & 9.90 & \multirow[t]{6}{*}{$1 / 2,3$} \\
\hline & 2 & Bazen & 142 & 25.6 & 43.40 & 11.70 & \\
\hline & 3 & Sık sık & 149 & 26.8 & 42.79 & 11.58 & \\
\hline & 4 & Her zaman & 228 & 41.1 & 40.67 & 11.85 & \\
\hline & & Toplam & 555 & 100 & 41.61 & 11.76 & \\
\hline & & $\mathrm{F}_{(3.551)}$ & 68 & & .05 & & \\
\hline
\end{tabular}

Tablo 10'de görüldüğü gibi dua sınav kaygısını yenmede bana yardımcı olur ifadesine hiçbir zaman diyenlerin sınav kaygısı skoru $\overline{\mathrm{X}}=35.58$ iken (bazen= $\overline{\mathrm{X}}=43.40$, sık sık=42.79), her zaman diyenlerin sinav kaygısı skoru ise $\overline{\mathrm{X}}=40.67$ 'dir. Tek yönlü varyans analizinde (Anova) örneklemin duanın sınav kaygısını yenmeye yardım ettiğine yönelik tutumu ile sınav kaygısı arasında istatiksel olarak anlamlı bir farklılaşma görülmüştür ( $F=3.368 \mathrm{p}=.001 \mathrm{p}<.05)$. Post Hoc (Tukey HSD) analizi ise bu durumun 1. grup ile 2 ve 3 . grup arasındaki farklılaşmadan kaynaklandığını göstermiştir. 
Tablo 12. Dua ile Sınav Kaygısını Yenme Tutumuna Göre Sınav Kaygısı (Chi-Square)

\begin{tabular}{|c|c|c|c|c|c|c|c|c|c|c|c|}
\hline \multirow{7}{*}{ 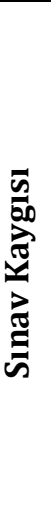 } & \multicolumn{11}{|c|}{ Dua sinav kaygısı ve stresini yenmede bana yardımcı olur } \\
\hline & & & 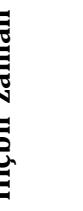 & & 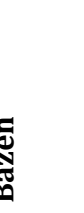 & & 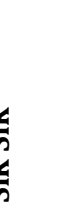 & & 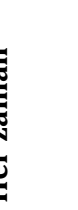 & & $\frac{\pi}{\frac{\pi}{2}}$ \\
\hline & & $\mathbf{N}$ & $\%$ & $\mathbf{N}$ & $\%$ & $\mathbf{N}$ & $\%$ & $\mathbf{N}$ & $\%$ & $\mathbf{N}$ & $\%$ \\
\hline & Düşük & 11 & 12.1 & 21 & 23.1 & 17 & 18.7 & 42 & 46.2 & 91 & 100 \\
\hline & Yüksek & 2 & 1.5 & 40 & 29.2 & 40 & 29.2 & 55 & 40.1 & 137 & 100 \\
\hline & Toplam & 13 & 5.7 & 61 & 26.8 & 57 & 25 & 97 & 42.5 & 228 & 100 \\
\hline & Chi-Square & & & & $=\overline{=14.48}$ & $\mathrm{df}=$ & $\mathrm{p}=.00$ & $\mathrm{p}<$. & & & \\
\hline
\end{tabular}

Tablo 12'de duanın sınav kaygı ve stresini yenmede yardımcı olduğuna yönelik tutum ile sınav kaygısı arasındaki bağımlılık durumu gösterilmektedir. Buna göre sınav kaygısı düşük olanların \%64,9’u (n=59) duanın sınav kaygısı ve stresini yenmede her zaman ve sıklıkla kendilerine yardımcı olduğunu ifade ederlerken, \%12,1'i (n=11) duanın sınav kaygısı ve stresini yenmede hiçbir zaman yardımcı olmadığını belirtmiştir. Bununla birlikte sınav kaygısı yüksek olanların \%69,3'ü $(n=95)$ duanın sınav kaygısı ve stresini yenmede her zaman ve sık sık kendilerine yardımcı olduğunu ifade ederlerken, \%1,2'si $(n=2)$ duanın sınav kaygısı ve stresini yenmede hiçbir zaman yardımcı olmadığını belirtmiştir. Ki-kare analizine göre sınav kaygısının duanın sınav kaygı ve stresini yenmede yardımcı olduğuna yönelik tutumla bir bağlantısı vardır $(\mathrm{p}=.002, \mathrm{p}<.05)$.

\begin{tabular}{|c|c|c|c|c|c|c|c|}
\hline \multirow{6}{*}{ 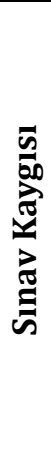 } & \multicolumn{2}{|r|}{$\begin{array}{c}\text { Besmele ve dua ile } \\
\text { başladığım } \\
\text { sınavlarda daha } \\
\text { başarılı olurum }\end{array}$} & $\mathbf{N}$ & $\%$ & $\overline{\mathbf{X}}$ & sS & $\begin{array}{c}\text { Tukey } \\
\text { HSD }\end{array}$ \\
\hline & 1 & Hiçbir zaman & 52 & 9.4 & 37.86 & 11.45 & $1 / 2$ \\
\hline & 2 & Bazen & 243 & 43.8 & 42.65 & 11.70 & \\
\hline & 3 & Sık sık & 134 & 24.1 & 42.09 & 11.54 & \\
\hline & 4 & Her zaman & 126 & 22.7 & 40.63 & 11.99 & \\
\hline & & Toplam & 555 & 100 & 41.61 & 11.76 & \\
\hline
\end{tabular}

Tablo 13’te görüldüğü gibi “Besmele ve dua ile başladığım sınavlarda daha başarılı olurum" ifadesine hiçbir zaman diyenlerin sınav kaygısı skoru $\overline{\mathrm{X}}=37.86$ iken (bazen $=\bar{X}=42.65$, sık sık=42.09), her zaman diyenlerin sınav kaygısı skoru ise $\overline{\mathrm{X}}=40.63$ 'dir. Tek yönlü varyans analizinde (ANOVA) besmele ile başlanılan sınavlarda daha başarılı olduğuna yönelik düşünce ile sınav kaygısı arasında istatiksel olarak anlamlı bir farklılaşma tespit edilmiştir ( $\mathrm{F}=2.785 \mathrm{p}=.040 \mathrm{p}<.05$ ). Post Hoc (Tukey HSD) analizi ise bu durumun 1. grup ile 2. grup arasindaki farklılaşmadan kaynaklandığını göstermiştir. 


\section{Tartışma ve Sonuç}

Hipotez A1. "Kadınların sınav kaygısı erkeklerinkinden daha yüksektir." Araştırmada (kadınların sınav kaygısı erkeklerinkinden daha yüksek) çıkmış olup, hipotez $A 1$ desteklenmiștir. Kadınların duygusal bir yapıya sahip olmaları bir duygu olan sınav kaygısının erkeklerden daha fazla tecrübe etmelerinde etkili olmuş olabilir. Yapılan pek çok başka araştırmada da kadınların sınav ve genel kaygı düzeyleri erkelerinkinden daha yüksek çıkmaktadır. Hembree'nin sınav kaygısı, etkileri ve tedavisi üzerine yapılmış 562 akademik çalışma üzerinde yaptığı meta analizde de kız öğrencilerin sınav kaygısı erkeklerinkinden daha yüksek çıkmıştır. ${ }^{58}$ Dündarın ${ }^{59}$, Çetin'in ${ }^{60}$ ve Kapıkıran'ın ${ }^{61}$ araştırmalarında da kadın öğrencilerin sınav kaygllarının erkek öğrencilerinkinden daha fazla olduğu tespit edilmiştir. Erözkan'ın araştırmasında ise erkek öğrencilerin sınav kaygısına yönelik kuruntu seviyeleri kadın öğrencilerden daha fazla çıkmıştır. Erözkan bu sonucu erkek öğrencilerin kişisel yeterliliklerini ortaya koyarak kendilerini yeterli ve güçlü hissetme ve başarılı olma bağlamında sınavlara atfettikleri değerlerin daha yüksek olması ile açıklamıştır.62 Genç'in ve Karakaş'ın araştırmalarında ise cinsiyet ile sınav kaygısı arasında anlamlı bir ilişki görülmemiştir.63

Hipotez A2. "Kadınların dini şuuru erkeklerinkinden daha yüksektir." Araştırmada (kadınların dini şuur düzeyleri erkeklerinkinden daha yüksek) çıkmış olup, hipotez A2 desteklenmiştir. Kadınların daha duygusal ve itaatkâr yapıya sahip olmaları erkeklerden daha yüksek dini şuur puanı elde etmelerinde etkili olmuş olabilir. Ancak cinsiyet ile dindarlık ilişkisi konusunda yapılmış diğer araștırmalara baktığımızda bazılarında erkeklerin, bazılarında kadınların daha yüksek dindarlık skorları elde ettikleri görülürken bazı araştırmalarda ise cinsiyet ile dindarlık arasında anlamlı ilişki bulunmamıştır. Küçükalp'in, Şengül'ün, Kımter'in, Güven'in, Hasankahyaoğlu'nun, Ayten'in, Yoğurtçu'nun, Dağlı'nın ve Gürsu'nun, araştırmalarında da benzer şekilde kadınların dindarlığı erkeklerinkinden daha yüksek çıkmıștır.64 Kuşat'ın, Koç'un, Ilgaz'ın, Sevindik'in, Yakut'un, Akgül'ün,

$58 \quad$ Hembree, "Correlates, Causes, Effects, and Treatment of Test Anxiety", 73.

59 Süleyman Dündar- Şenay Yapıcı, Birol Topçu, "Üniversite Öğrencilerinin Bazı Kişilik Özelliklerine Göre Sınav Kaygısının İncelenmesi” GÜ, Gazi Eğitim Fakültesi Dergisi, 28/1 (2008), 171.

60 Şaban Çetin, "Eğitim Fakültesi Öğrencilerinin Kamu Personeli Seçme Sınavına (Kpss) Yönelik Kaygılarının İncelenmesi”, Millî Eğitim, 197 (2013), 158.

61 Şahin Kapıkıran, "Üniversite Öğrencilerinin Sınav Kaygısının Bazı Psiko-Sosyal Değișkenlerle İlişkisi Üzerine Bir İnceleme”, Pamukkale Üniversitesi Eğitim Fakültesi Dergisi, 11/34 (2002), 34; Dilek Çakıcı, "Yabancı Dil Öğrenenlerin Sınav Kaygı Düzeyleri”, Turkish Studies, 10/7 (2015), 243.

62 Atılgan Erozkan, “Üniversite Öğrencilerinin Sınav Kaygısı ve Başa çıkma Davranışları”, Muğla Üniversitesi Sbe Dergisi, 12 (2004), 31.

63 Murat Genç, "İlköğretim Öğrencilerinin Sınıf ve Cinsiyete Göre Sınav Kaygı Düzeylerinin Belirlenmesi", CBÜ Sosyal Bilimler Dergisi, 11/l (2013), 85; Ahmet Canan Karakaş, "Paylaşma Tutumlarının Sınav Kaygısı-Gelecek Kaygısı İle İlişkisi (Sakarya İli Örneği)”, İtobiad (2013), 145.

64 Emine Küçükalp, "Ahlaki Yargı Gelişimi ve Dindarlık İlişkisi”, (yüksek lisans tezi, Uludağ Üniversitesi Sosyal Bilimler Enstitüsü, 2004), s. 77; Fatma Şengül, "Dindarlık ve Ruh Sağlığı İlişkisi" (yüksek lisans tezi, Marmara Üniversitesi Sosyal Bilimler Enstitüsü, 2007), s. 124; 
Mehmedoğlu'nun ve Çapçıoğlu'nun araştırmalarında ise erkeklerin dindarlığı kadınlarınkinden daha yüksek çıkmıştır.65

Hipotez A3. "Sosyo-ekonomik düzey yükseldikçe içsel dini motivasyon ve dini şuur azalır." Araştırmada (sosyo-ekonomik durumu yüksek olanların en düşük içsel dini motivasyon ve dini şuur skorları) elde ettikleri görüldügünden dolayı hipotez A4 desteklenmiştir. Yapılan pek çok araştırmada da benzer şekilde sosyo-ekonomik düzeyi yüksek olan örneklemin dindarlığı düşük çıkmaktadır.66 İnsanoğlu sağlıklı, güçlü ve ekonomik yönden zengin olduğunda kolaylıkla azıtabilmekte, kul olduğunu unutup nefsini tanrılaştırabilmektedir. Ancak aynı insanoğlu ciddi sıkıntı ve yaşamsal tehditle karşılaştığında Allah'a sığınıp, dine yönelebilmektedir. Kur'an'ı Kerim'de “Denizde başınıza bir felaket geldiği zaman, Allah'tan başka yalvardığınız bütün putlar kaybolur. Allah sizi tehlikeden kurtarıp karaya çıkarınca da yüz çevirirsiniz. Zaten insan çok nankördür"67, "İnsana bir sıkıntı dokunduğu zaman, gerek yan yatarken, gerek otururken, gerek dikilirken bize dua eder. Kendisinden sıkıntısını gideriverdik mi sanki kendisine dokunan o sıkıntı için bize hiç yalvarmamış gibi aldırmadan geçer gider" 68 ayetlerinde insanoğlunun bu çlkarcı eğiliminden bahsedilmektedir.

Nurten Kımter, "Benlik Saygısı ve Dindarlık İlişkisi”, (doktora tezi, Uludağ Üniversitesi Sosyal Bilimler Enstitüsü, 2008), s. 213; Hülya Güven, "Depresyon ve Dindarlık İlişkisi”, (yüksek lisans tezi, Marmara Üniversitesi Sosyal Bilimler Enstitüsü 2008), s. 101; Havva Rabia Hasankahyaoğlu, "Dindarlık Empati İlişkisi" (yüksek lisans tezi, Selçuk Üniversitesi Sosyal Bilimler Enstitüsü, 2008), s. 54; Ali Ayten, "Prososyal Davranışlarda Dindarlık ve Empatinin Rolü", (doktora tezi, Marmara Üniversitesi Sosyal Bilimler Enstitüsü, 2009), s. 119; Fatma Yoğurtçu, "Yetişkinlerde Dindarlık ve Ruh Sağlığı", (yüksek lisans tezi, Sakarya Üniversitesi Sosyal Bilimler Enstitüsü, 2009), s. 52; Emel Nuriye Dağlı, "Yaşlılarda Ölüm Kaygısı ve Dindarlık" (yüksek lisans tezi, Selçuk Üniversitesi Sosyal Bilimler Enstitüsü, 2010), s. 87; Orhan Gürsu, "Ergenlik Döneminde Psikolojik Sağlık ve Dindarlık İlişkisi” (doktora tezi, Selçuk Üniversitesi Sosyal Bilimler Enstitüsü, 2011), s. 170.

65 Ali Kuşat, "Ergenlerde Allah Tasavvuru", Dindarlı̆̆ın Sosyo-Psikolojisi, (edt. Ünver Günay, Celalettin Çelik), Adana: Karahan Kitabevi, 2006, s. 146; Mustafa Koç, "Yetişkinlik Döneminde Dindarlık İle Benlik Kavramı Değişkenleri Arasındaki İlișki” (doktora tezi, Uludağ Üniversitesi Sosyal Bilimler Enstitüsü, 2008), s. 126; Abdulkadir Ilgaz, "Depresyon ve Dindarlık İlişkisi, Kastamonu Örneği”, (yüksek lisans tezi, Erciyes Üniversitesi Sosyal Bilimler Enstitüsü, 2015), s. 63; Durmuş Sevindik, "Orta Yaş Dönemi Bireylerde Dindarlık-Mutluluk İliş̧kisi: Denizli Örneği”, (yüksek lisans tezi, Süleyman Demirel Üniversitesi Sosyal Bilimler Enstitüsü, 2015), s. 76; Selahattin Yakut, "Öğretmenlerde Yabancılaşma, Yalnızlık ve Dindarlık İlişkisi: Polatlı Örneği”, (doktora tezi, Süleyman Demirel Üniversitesi Sosyal Bilimler Enstitüsü, 2016), s. 111; Ömer Akgül, "Din Karşıtı Propaganda ve Dindarlık", (yüksek lisans tezi, Marmara Üniversitesi Sosyal Bilimler Enstitüsü, 2007), s. 91; Ali Ulvi Mehmedoğlu, Kişilik ve Din, İstanbul: Dem Yayınları, 2004, s. 68; İhsan Çapçığlu, "Sosyo-Politik Tutumlar Ve Dindarlık İliş̧kisi -İlahiyat Fakülteleri Örneği” (doktora tezi, Ankara Üniversitesi Sosyal Bilimler Enstitüsü, 2008), s. 119. Naci Kula, "Gençlik Döneminde Kimlik ve Din”, Gençlik Din ve Değerler Psikolojisi, (edt. Hayati Hökelekli), Ankara: Ankara Okulu Yayınları, 2002, s. 42; Necmi Karslı, "Gençlerde Özsaygı ve Dindarlık İlişkisi”, Avrasya Sosyal ve Ekonomi Araştırmaları Dergisi, 4 (2017), 29; Ali Albayrak, "Caferilerde Dini ve Sosyal Hayat (Ankara Keçiören Örneği)”, (yüksek lisans tezi, Ankara Üniversitesi Sosyal Bilimler Enstitüsü, 2006), s. 127; Emine Küçükalp "Ahlaki Yargı Gelişimi ve Dindarlık İlişskisi” (yüksek lisans tezi, Uludağ Üniversitesi Sosyal Bilimler Enstitüsü, 2004), s.84; Elif Elifoğlu Çurum, "Dindarlık ve İş Stresi İlişkisi (Samsun Örneği)", (yüksek lisans tezi, 
Hipotez A4. "İçsel dini motivasyon ve dini şuur arttıkça sigara kullanımı azalır." Araştırmada örneklemin (içsel dini motivasyon ve dini şuur düzeyi arttıkça sigara kullanım oranı anlamlı bir şekilde azaldığı) görülmüş olup, hipotez A4 desteklenmiştir. Sigara kullanımının kanser, kardiyovasküler hastalıklar, solunum ve akciğer hastalıkları, göğüs kanseri gibi pek çok ölümcül hastalığa neden olduğu yapılan araştırmalarla bilimsel olarak ispatlanmıştır. Dünya genelinde sigara neden olduğu hastalıklardan ötürü yılda yaklaşık 5-6 milyon insan hayatını kaybetmekte, 2030 yılına kadar bu sayının 10 milyona ulaşacağı tahmin edilmektedir. ${ }^{69}$ İslam'da genel bir prensip olarak temiz ve güzel şeylerin helal, pis ve zararlı şeyler haram kılınmıştır. Kur'ân-ı Kerim'de "Allah israf edenleri sevmez"70 buyurulmaktadır. Hanefi fakihleri sigaranın, sağlığa zararlı olması, israfa yol açması ve ailenin nafakasının teminine engel olmasından ötürü tahrimen (harama yakın) mekruh olduğu görüşündedirler. Sigaranın sağlığa zararlı bir madde olması ve dinen de yasaklanmış olması araştırmamızda içsel dini motivasyonu ve dini şuuru yüksek bireylerin sigara kullanımlarının düşük çıkmasında etkili olmuş olabilir. Bu konuda yapılan başka araştırmalarda da sigara kullanımı ile içsel dini motivasyon ve dini şuur ile sigara kullanımı arasında anlamlı negatif ilişkiler tespit edilmiştir. ${ }^{71}$

Hipotez B1. "Dini şuur, bini bilinç ve dini davranış arttıkça sınav kaygısı azalır." Araştırmada örneklemin (dini şuur, dini bilinç ve dini davranış puanları yükseldikçe sınav kaygı düzeyinin yükseldiği) tespit edilmiş olup, hipotez B1 desteklenmemiştir. Bu sonuç üzerinde cinsiyet faktörünün kısmen etkili olduğunu düşünmekteyiz. Zira Tablo 2'de örneklemin \%66,1'ini oluşturan kız öğrencilerin sınav kaygısı ortalaması $\overline{\mathrm{X}}=43.21$, örneklemin \%33,9'unu oluşturan erkeklerin sınav kaygısı ortalaması ise $\overline{\mathrm{X}}=38.48$ çıkmıştı. Ayrıca Ki-Kare analizine göre de cinsiyet ile sınav kaygısı arasında bir bağımlılık bulunmuştu (X=13.245, df=1 p=.000, p<.05). Ayrıca Tablo 3'teki verilerde kadınların dini şuur ortalaması $\bar{X}=83.60$ iken, erkeklerin aynı ölçekten aldıkları ortalama skor $\overline{\mathrm{X}}=79.94$ çıkmıştı. Dolayısıyla örneklemin çoğunluğunu oluşturan kadın öğrencilerin dindarlık ve sınav kaygısı düzeylerinin yüksek olması dini şuur ve sınav kaygısı arasında pozitif ilişki çıkmasında etkili olmuş olabilir. Bununla birlikte başarı için bir miktar kaygı gereklidir. Dolayısıyla dini yaşantı sonucunda sorumluk ve disiplin duyguları kazanan dindarların başarı için çabalama sürecinde kaygı tecrübe etmeleri doğal olarak görülebilir. Şeftalici'nin lise öğrencilerin üzerinde yaptı̆̆ı araştırmada da öznel dindarlık ile sınav kaygısı arasında güçlü pozitif yönlü ilişki tespit edilmiştir. ${ }^{72}$ Kartopu'nun araştırmasında benzer şekilde kendisini çok dindar görenler en yüksek durumluk kaygı puanı aldıkları görülmüştür. ${ }^{73}$ Karakaş'ın lise öğrencileri üzerinde yaptığı araştırmada da

\footnotetext{
69 George C. Chen, Cigarette Consumption And Health Effects, New York: Nova Science Publishers, 2013, s. 7.

71 Karslı, Mutluluk ve Dindarlık, s. 232; Karslı, "Gençlerde Özsaygı ve Dindarlık İlișkisi”, 31.

72 Büşra Şeftalici, "Lise Son Sınıf Öğrencilerinde Sınav Kaygısı ve Maneviyat Șanlıurfa-Viranșehir Örneği" (yüksek lisans tezi, Çukurova Üniversitesi Sosyal Bilimler Enstitüsü, 2017), s. 49.

73 Kartopu, "Lise Öğrenci Ve Öğretmenlerinin Durumluk Ve Sürekli Kaygı Düzeylerinin Bazı Değişkenler Açısından İncelenmesi (Kahramanmaraş Örneği)", 164.
} 
dini eğitim alan İmam Hatip Lisesi öğrencilerinin sınav kaygısı düzeylerinin düz lise öğrencilerininkinden daha fazla olduğu bulunmuştur. ${ }^{74}$ Hayta'nın ilahiyat fakültesi öğrencileri üzerinde yaptığı araştırmada dua ibadeti ile kaygı arasında anlamlılık derecesine ulaşmayan pozitif ilişki tespit edilmiștir. ${ }^{75}$ Koeing ve Larson'un araştırmasında kaygı ve dindarlık ilişkisi üzerine 76 araştırma incelenmiştir. İncelenen araştırmaların çoğunluğunda dindarlığın yüksek olan gruplarda daha düşük seviyelerde kaygı ve korku duyguları bulunmuş, 10 araştırmada ise daha dindar olan gruplarda daha yüksek seviyede kaygı tespit edilmiştir. ${ }^{76}$ Koç'un lise öğrencileri üzerinde yaptığı araștırmada sürekli namaz kılanların daha az stres ve kaygı hissettikleri görülmüştür. ${ }^{77}$

Hipotez B2. "Dua sınav kaygısının dindirilmesinde etkilidir." Araştırmada "Dua sınav kaygısı ve stresini yenmede bana yardımcı olur" ifadesine sik sık ve her zaman şeklinde kanaat bildirenlerin oranı \%67,9 seviyesinde olmuş, dolayısıyla hipotez B2 desteklenmiştir. Araştırmada duanın sınav kaygı ve stresini yenmede kendilerine hiç yardımcı olmadığını düşünen $36(\% 6,5)$ kişi en düşük sınav kaygısı puanı almış olsalar da örneklemin büyük çoğunluğuna göre (sık sık ve her zaman=377 kişi \%67,9) dua sınav kaygısını dindirmede kendilerine yardımcı olmaktadır. Araştırmamızın ilk kısmında ifade ettiğimiz gibi kaygının da dâhil olduğu tüm negatif duygular bizatihi kötü değillerdir. Negatif duyguların belli bir seviyede tecrübe edilmesi bireyin maddi ve manevi varlığını koruması, çalışması, üretmesi ve başarılı olması için gereklidir. Kaygı ve diğer negatif duygular sürekli ve aşırı bir şekilde tecrübe edildiğinde tedavi edilmesi gereken bir sorun haline gelmektedirler. ${ }^{78}$ Araştırmamızda sınav kaygısını yüksek olan örneklemin kaygı düzeylerinin faydalı kaygı seviyesinde mi yoksa APA'nın kaygı bozukluğu için belirlediği kriter olan 6 ay veya daha uzun süre devam eden, aşırı bir kaygı mı olduğu bu araştırma bağlamında incelenmemiştir. Kaygı duygusunun anlamsız mantıksız düşünceleri içeren bilişsel yönü bir de otonom bedensel tepileri içeren duygusal yönü bulunmaktadır. İslam bireye güven telkin ederek, hayata ve olaylara yönelik gerçekçi bir bakış açısı ve anlam kazandırarak kaygıya neden olan anlamsız mantık dışı, tekrarlayan düşüncelerin oluşmasını önlemektedir. Kaygının duygusal yönü ile ilgili olarak, kaygının bedenin içsel dengesini bozması sonucunda oluşan otonom tepkilere yönelik olarak ise abdest alma ${ }^{79}$, toprağa temas etme ${ }^{80}$, bedenin

\footnotetext{
74 Karakaş, "Paylaşma Tutumlarının Sınav Kaygısı-Gelecek Kaygısı İle İlişkisi (Sakarya İli Örneği)”, 135.

75 Akif Hayta, "İbadetler ve Ruh Sağlığı", Gençlik Din ve Değerler Psikolojisi, (edt. Hayati Hökelekli), Ankara: Ankara Okulu Yayınları, 2002, s. 135.

76 Harold G. Koenig, David B. Larson, "Religion and mental health: evidence for an Association", International Review of Psychiatry, 13 (2001), 71.

77 Mustafa Koç, "Ergenlik Döneminde Dua Ve İbadet Algılarının Ruh Sağlı̆̆ına Etkileri Üzerine Bir Alan Araştırması", Sakarya Üniversitesi İlahiyat Fakültesi Dergisi, 10 (2004), 142.

78 American Psychiatric Association, Diagnostic And Statistical Manual Of Mental Disorders, s. 189,190 .

79 Ebû Dâvud, "Edeb", 4

80 Tirmizi, “Fiten”, 26; Ahmed b. Hanbel, Müsned, III: 61.
} 
konumunu değiştirme ${ }^{81}$, dua etme ${ }^{82}$ gibi bir takım davranışsal önerilerde bulunulmaktadır. Hallahmi ve Argyle'in "Dini Davranış, Inanç ve Tecrübe Psikolojisi” isimli eserinde dini inancın kaygı azaltıcı bir mekanizma olduğuna dair pek çok araştırma bulgusuna yer verilmiştir. Eserin 9-11. Bölümlerinde yer alan kişilik ve din ilişkisi üzerine olan araştırma bulguları, özellikle 7. Bölümde yer alan dini dönüşüm yapanlardan elde edileni bulgular dinin/dini dönüşümün kaygıyı azalttığı ve güvenli desteklediğini göstermiştir. ${ }^{83}$

Hipotez B3. "Dua ve besmele ile sınava başlamak sınav başarısını olumlu etkiler." Araştırmada "besmele ve dua ile başladığım sınavlarda daha başarılı olurum" ifadesine örneklemimizin \%46,8'i (slk sık ve her zaman), \%43,8'i bazen, \%9,4'u ise hiçbir zaman şeklinde cevap vermiştir. Bu verilere göre örneklemin çoğunluğu besmele ve dua ile başladıkları sınavlarda başarılı olduklarını bildirmiş olup, hipotez B3 desteklenmiştir. Duanın çeşitli yaşamsal sıkıntıları gidermede mucizevi etkilere neden olduğu çeşitli araştırmalarla tespit edilmiştir. Dua sayesinde inanan birey sıkıntılı durum karşısında Allah'tan yardım ister, O'na güvenir, teselli olur. Bazen birey kimseye anlamadığı sorunlarını dua sayesinde Rabbine arz ederek psikolojik bir boşalma sağlar ve yardım talebinde bulunur. Besmele insanın zihnini karıștırma potansiyeli olan Şeytan'ın etkilerinden ${ }^{84}$ Allah'a sığınma ve onun adı ile işe başlama anlamına gelmektedir. Hz. Muhammed 'Yüce Allah'ı anarak başlanmayan her anlamlı söz veya iş, bereketsizdir/sonuçsuzdur." ${ }^{85}$ buyurarak başarıya ulaşmada besmelenin önemini vurgulamıştır.

Hipotez B4. "Dua sınav kaygısını yenmede her zaman yardımcı olur, diyenlerin sinav kaygısı bazen ve sık sık diyenlerinkinden daha düşük olur." Araştırmada dua sınav kaygısını yenmede bana yardımcı olur ifadesine her zaman ( $n=228, \% 41,1)$ şeklinde görüş bildiren örneklemin sınav kaygısı düzeyi aynı ifadeye bazen ( $n=142, \% 25,6)$ ve sık sık $(n=149, \% 26,8)$ şeklinde görüş bildirenlerden daha düşük çıkmış olup, hipotez $B 4$ desteklenmiştir. Araştırma bulgularında duanın kendilerine sınav kaygısını yenmede hiç yardımı olmadığını ifade eden 36 kişi $(\% 6,5)$ en düşük sınav kaygısı ortalamasını almış olsalar da duanın sınav kaygısını yenmede her zaman kendilerine yardımcı olduğunu bildirenlerin oranı $(n=228, \% 41,4)$ gruplar içinde en kalabalık grubu oluşturmaktadır ve birinci grup hariç gruplar içinde en düşük sınav kaygısı ortalamasına sahip olmuşlardır. Doğan'ın farklı yaş gruplarından bireyler üzerinde yaptığı araştırmada da örneklemin çoğunluğu depresyon $(\% 75,6)$ ve stres $(\% 65,33)$ ile mücadelede duanın kendilerine yardımcı olduğunu bildirmiştir. Doğan'a göre dua eden bireyin isteğini her șeye gücünün yettiğine inandığı Allah'a

\footnotetext{
81 Ebû Dâvud, “Edeb”, 4.

82 Furkan 25/77; Mü'min 40/60; A'raf 7/55.

83 Benjamin Beit-Hallahmi, Michael Argyle, The Psychology of Religious Behaviour, Belief and Experience, New York: Routledge, 1997, s. 234.

84 Bakara 2/268; En’am 6/112; Buhârî, "İtikâf", 11; Müslim, "Selâm", 23-25; Ebû Dâvûd, "Savm", 79; “Edeb”, 81.

85 Ahmed b. Hanbel, Müsned, II: 360
} 
yöneltmesi ve sığınması depresyon ve stresten kurtulmasına yardımcı olmaktadır. 86 İşlek'in lise öğrencileri üzerinde yaptığı araștırmada dua tutumu ile durumluk ve sürekli sınav kaygısı arasında anlamlı negatif ilişki tespit edilmiştir. ${ }^{87}$

Hipotez B5. "Besmele ve dua ile başladığım sinavlarda her zaman daha başarılı olurum diyenlerin sınav kaygısı bazen ve sık sık diyenlerinkinden daha düşük olur." Araştırmada besmele ve dua ile başladığım sınavlarda daha başarılı olurum ifadesine her zaman ( $\mathrm{n}=126, \% 22,7)$ şeklinde görüş bildiren örneklemin sınav kaygısı aynı ifadeye bazen $(n=243, \% 43,8)$ ve sık sık $(n=134, \% 24,1)$ şeklinde görüş bildirenlerden daha düşük çıkmış olup hipotez B5 desteklenmiştir. Bununla birlikte besmele ve dua ile başladığı sınavlarda hiç başarılı olmadığını ifade eden 52 kişi $(\% 9,4)$ en düşük sınav kaygısını almış olsa da 503 kişi $(\% 90,6)$ besmele ve dua ile başladığı sınavlarda bazen, sıklıkla ve her zaman başarılı olduklarını bildirmişlerdir. $\mathrm{Bu}$ sonuçlardan örneklemin çoğunluğunun besmele ve dua ile başladıkları sınavlarda bir şekilde daha başarılı oldukları sonucu çıkmıştır. Doğan'ın araştırmasında da benzer şekilde örneklemin yarıdan fazlası duadan kesinlikle fayda gördügünü belirtmiş, diğer bir kısmı genellikle ve ara sıra faydasını gördüğünü ifade etmiş, çok az bir kısmı ise duanın faydasını görmediği bildirmiştir. ${ }^{88}$

Sonuç olarak bu araştırmada insanın duygu, düşünce ve davranışları üzerinde eşsiz etkisi bulunan dinin ve dua ibadetinin sınav kaygısı üzerindeki etkisi incelenmiştir. Kaygı, endişeli ve korkulu duyguları ifade etmek için kullanılan evrensel bir insani duygudur. Kaygının sürekli ve aşırı bir şekilde tecrübe edilmesi kaygı bozukluğu hastalığının belirtisidir. Kaygının içgüdüsel, biyolojik, bilişsel ve davranışsal kaynakları bulunmaktadır. Sınav kaygısı bir sınav veya değerlendirilme durumundaki performansa bağlı olarak olumsuz sonuç elde etme olasılığının yol açtığı endişeye eşlik eden bilişsel, duygusal ve davranışsal tepkilerdir. Aşırı ve kontrol edilemeyen sınav kaygısının tedavisinde davranışsal ve bilişsel terapi, sistematik duyarsızlaştırma, biofeedback ve ilaç tedavisi gibi yöntemler kullanılmaktadır. Kaygının temelinde abartılmış, gerçek dışı düşünceler, özgüven eksikliği, mantıklı ve yapıcı düşünememe yatmaktadır. Din hayata, ölüme ve negatif yaşamsal olaylara tatmin edici anlam sağlayarak, güven duygusu sağlayarak, tevekkül düşüncesi, dua ve diğer ibadetler ile bireye sınav ve diğer negatif olaylara yönelik gerçekçi bakış açısı, ilahi yardım duygusu sağlayarak sınav kaygısı veya yaşamsal olayların neden olduğu kaygı ve stresin ektilerinden bireyi korumaktadır.

Araştırmada sınav kaygısı ile dini şuur, içsel dini motivasyon ve dua ibadeti arasındaki ilişki incelenmiş ve şu sonuçlara ulaşılmıştır. Kadınların sınav kaygısı erkeklerinkinden daha yüksektir. İçsel dini motivasyon ve dini şuur arttıkça sigara kullanımı azalmaktadır. Sosyo-ekonomik durum yükseldikçe içsel dini motivason ve

86 Mecbure Doğan, "Duanın Psikolojik ve Psikoterapik Etkileri” (yüksek lisans tezi, Uludağ Üniversitesi Sosyal Bilimler Enstitüsü, 1997), s. 79,84.

87 Mustafa İşlek, "Ergenlerde Kaygı ve Duanın Çeşitli Değişkenler Açısından İncelenmesi”, (yüksek lisans tezi, Recep Tayyip Erdoğan Üniversitesi Sosyal Bilimler Enstitüsü, 2016), s. 152.

88 Doğan, “Duanın Psikolojik ve Psikoterapik Etkileri”, 73. 
dini şuur azalmaktadır. Dini şuur, dini bilinç ve dini davranış ile sınav kaygısı arasında pozitif yönlü ilişki vardır. Dua ve besmele ile sınava başlamak sınav kaygısını yenmede etkilidir. Araştırmada genel olarak dindarların daha fazla kaygılı oldukları ve duanın sınav kaygısı ve stresini yenmede etkili olduğu görülmüştür. Bulgularımız dindarlık ve kaygı ilişkisi üzerine yapılan başka araştırma sonuçları ile uyumludur. Dindarlık ve sınav kaygısı ilişkisinin daha net bir şekilde tespit edilmesi için bu konuda başka deneysel araştırmalar yapılmalıdır. Ayrıca duanın birey üzerindeki etkisinin sadece psikolojik olmadığı, insanın ruhsal dünyasının dışında ilahi müdahale yönünün varlığının tespiti için Harris ve Byrd'un araştırmalarındaki gibi deney grubundaki bireylere yönelik haber verilmeksizin tanımadıkları insanlar tarafından yapılan gıyabi duaların bireyler üzerindeki etkilerinin incelendiği araştırmalar gerçekleştirilmelidir.

\section{Kaynakça}

Acklin, Marwin W. - Brown, Earl C. - Mauger, Paul A. "The Role of Religious Values in Coping with Cancer", Journal of Religion and Health, 22/4 (1983), 322-333.

Akgül, Ömer, "Din Karşıtı Propaganda ve Dindarlık", (yüksek lisans tezi, Marmara Üniversitesi Sosyal Bilimler Enstitüsü, 2007).

Albayrak, Ahmet, Gençlerde Dua Psikolojisi, İstanbul: Düşünce Yayınları, 2013.

Albayrak, Ali, "Caferilerde Dini ve Sosyal Hayat (Ankara Keçiören Örneği)" (yüksek lisans tezi, Ankara Üniversitesi Sosyal Bilimler Enstitüsü, 2006).

American Psychiatric Association, Diagnostic And Statistical Manual of Mental Disorders, 5. Baskl, Washington: American Psychiatric Association, 2013.

Arthur Freeman - Robert A. DiTomasso, "Cognitive Concepts of Anxiety", Textbook of Anxiety Disorders, (ed. Dan J. Stein, Eric Hollander), Washington: American Psychiatric Publishing, 2002.

Aydın, Fatma, "Akademik Başarının Yordayıcısı Olarak Akademik Güdülenme, Öz Yeterlilik ve Sınav Kaygısı", (yüksek lisans tezi, Hacettepe Üniversitesi, Sosyal Bilimler Enstitüsü, 2010).

Ayten, Ali, "Prososyal Davranışlarda Dindarlık ve Empatinin Rolü" (doktora tezi, Marmara Üniversitesi Sosyal Bilimler Enstitüsü, 2009).

Ayten, Ali, "Üniversite Öğrencilerinde Ölüm Kaygısı: Türk ve Ürdünlü Öğrenciler Üzerine Karşılaştırmalı Bir Araştırma", Din Bilimleri Akademik Araştırma Dergisi, 9/4 (2009), 85-108.

Azhar, M. Z.- Varma, S. L. - Dharap, A. S. "Religious Psychotherapy in Anxiety Disorder Patients." Acta Psychiatrica Scandinavica, 90/1 (1994), 1-3.

Budak, Selçuk, Psikoloji Sözlüğü, Ankara: Bilim ve Sanat Yayınları, 2009.

Büşra Şeftalici, "Lise Son Sınıf Öğrencilerinde Sınav Kaygısı ve Maneviyat ŞanlıurfaViranşehir Örneği" (yüksek lisans tezi, Çukurova Üniversitesi Sosyal Bilimler Enstitüsü, 2017).

Byrd, Randolph C., "Positive Therapeutic Effects Of Intercessory Prayer in A Coronary Care Unit Population", Southern Medical Journal, $81 / 7$ (1988), 826-829.

Cassady, Jerrell C.- Johnson - Ronald E., "Cognitive test anxiety and academic performance". Contemporary Educational Psychology, 27/2, (2002), 270-295.

Chen, George C., Cigarette Consumption And Health Effects, New York: Nova Science Publishers, 2013. 
Clark, Carolyn Chambers, Living Well With Anxiety, Harpercollins Ebooks, 2006.

Clark, David A.- Beck, Aaron T., Cognitive Therapy of Anxiety Disorders, New York: The Guilford Press, 2010.

Coetzer, Rudi, Anxiety and Mood Disorders Following Traumatic Brain Injury: Clinical Assessment and Psychotherapy The Brain Injuries Series, New York: Routledge, 2018.

Çakıcı, Dilek, "Yabancı Dil Öğrenenlerin Sınav Kaygı Düzeyleri”, Turkish Studies, 10/7 (2015), 243.

Çapçığlu, İhsan, "Sosyo-Politik Tutumlar ve Dindarlık İlişkisi -İlahiyat Fakülteleri Örneği" (doktora tezi, Ankara Üniversitesi Sosyal Bilimler Enstitüsü, 2008).

Çetin, Şaban, “Eğitim Fakültesi Öğrencilerinin Kamu Personeli Seçme Sınavına (Kpss) Yönelik Kaygılarının İncelenmesi”, Millî Eğitim, 197 (2013), 158.

Çurum, Elif Elifoğlu, "Dindarlık ve İş Stresi İlişkisi (Samsun Örneği)”, (yüksek lisans tezi, Ondokuz Mayıs Üniversitesi Sosyal Bilimler Enstitüsü, 2015).

Dağlı, Emel Nuriye, "Yaşlılarda Ölüm Kaygısı ve Dindarlık" (yüksek lisans tezi, Selçuk Üniversitesi Sosyal Bilimler Enstitüsü, 2010).

Darwin, Charles, The Expression of the Emotions in Man and Animals, (edt. Francis Darwin), New York: Cambridge University Press, 2009.

Doğan, Mecbure, "Duanın Psikolojik ve Psikoterapik Etkileri" (yüksek lisans tezi, Uludağ Üniversitesi Sosyal Bilimler Enstitüsü, 1997).

Domschke, Katharina - Deckert, Jürgen, "Genetics", Behavioral Neurobiology of Anxiety and Its Treatment, (edt. Murray B. Stein 1 Thomas Steckler), New York: Springer, 2010, 63.

Dündar, Süleyman - Yapıcı, Şenay- Topçu, Birol, "Üniversite Öğrencilerinin Bazı Kişilik Özelliklerine Göre Sınav Kaygısının İncelenmesi”, GÜ, Gazi Eğitim Fakültesi Dergisi, 28/1 (2008), 171-186.

İsfehânî, Ragıb, Müfredat, Kur'an Kavramları Sözlüğü, (çev. Abdulbaki Güneş, Mehmet Yolcu), Çıra Yayınları. İstanbul, 2012.

Ellis, Albert - MacLaren, Catharine, Rational Emotive Behavior Therapy, California: Impact Publishers, 1998.

Erdem, Hüsamettin, Problematik Olarak Din-Felsefe Münasebeti, Konya: Sebat Ofset Matbaacıllk, 1997.

Erozkan, Atılgan, "Üniversite Öğrencilerinin Sınav Kaygısı ve Başa çıkma Davranışları”, Muğla Üniversitesi Sbe Dergisi, 12 (2004), 13-38.

Frankl, Viktor, İnsanın Anlam Arayışıı, (çev. Selçuk Budak), İstanbul: Öteki Yayınevi, 2007.

Freud, Sigmund, Interpretion of Dreams, New York: Courier Dover Publications, 2015.

Gaudry, Eric - Spielberger, Donald, Anxiety And Educational Achievement. New York: Wiley, 1971.

Genç, Murat, "İlköğretim Öğrencilerinin Sınıf ve Cinsiyete Göre Sınav Kaygı Düzeylerinin Belirlenmesi", CBÜ Sosyal Bilimler Dergisi, 11/1 (2013), 85-95.

Ghinassi, Cheryl Winning, Anxiety, Oxford: Abc Clio, 2010.

Gürsu, Orhan, "Ergenlik Döneminde Psikolojik Sağlık ve Dindarlık İlişkisi”, (doktora tezi, Selçuk Üniversitesi Sosyal Bilimler Enstitüsü, 2011).

Güven, Hülya, "Depresyon ve Dindarlık İlişkisi", (yüksek lisans tezi, Marmara Üniversitesi Sosyal Bilimler Enstitüsü 2008).

Hallahmi, Benjamin Beit - Argyle, Michael, The Psychology of Religious Behaviour, Belief and Experience, New York: Routledge, 1997. 
Hasan Kahyaoğlu, Havva Rabia, "Dindarlık Empati İlişkisi" (yüksek lisans tezi, Selçuk Üniversitesi Sosyal Bilimler Enstitüsü, 2008).

Hayta, Akif, "İbadetler ve Ruh Sağlığı”, Gençlik Din ve Değerler Psikolojisi, (edt. Hayati Hökelekli), Ankara: Ankara Okulu Yayınları, 2002, 135.

Hembree, Ray, "Correlates, Causes, Effects, and Treatment of Test Anxiety", Review of Educational Research, 58/1 (1988), 47-77.

Hettema John M. - Neale Michael C. - Kendler, Kenneth S., "A Review And Meta-Analysis of The Genetic Epidemiology Of Anxiety Disorders", Am J Psychiatry, 158/10 (2001) 1568-78.

Hiott, Walter D. - Labbate, Lawrence, "Evaluation and Management of Neurobehavioral Syndromes of Traumatic Brain Injury", NeuroRehabilitation, 17/4 (2002), 345-355.

Ilgaz, Abdulkadir, "Depresyon ve Dindarlık İlișkisi, Kastamonu Örneği", (yüksek lisans tezi, Erciyes Üniversitesi Sosyal Bilimler Enstitüsü, 2015).

Izard, Carroll E., "Anxiety: A Variable Combination Of Interacting Fundamental Emotions", Anxiety Current Trends In Theory And Research, (edt. Charles D. Spielberger), New York: Academic Press, 1972, I.

Kabalcı, Tuğba, "Akademik Başarının Yordayıcısı Olarak Benlik Saygısı, Sınav Kaygısı ve Sosyo-Demografik Değişkenler", (yüksek lisans tezi, Hacettepe Üniversitesi Sosyal Bilimler Enstitüsü, 2008).

Kapıkıran, Șahin, “Üniversite Öğrencilerinin Sınav Kaygısının Bazı Psiko-Sosyal Değișkenlerle İlişkisi Üzerine Bir İnceleme", Pamukkale Üniversitesi Eğitim Fakültesi Dergisi, 11/34 (2002), 34-43.

Karaca, Faruk, "Din Psikolojisinde Metot Sorunu ve Bir Dindarlık Ölçeğinin Türk Toplumuna Standardizasyonu", EKEV Akademi Dergisi, 3/1 (2001), 196-199.

Karaca, Faruk, Ölüm Psikolojisi, İstanbul: Beyan Yayınları, 2000.

Karakaş, Ahmet Canan, "Paylaşma Tutumlarının Sınav Kaygısı-Gelecek Kaygısı İle İlişkisi (Sakarya İli Örneği)", Ittobiad (2013), 136-157.

Karslı, Necmi, "Gençlerde Özsaygı ve Dindarlık İlişkisi", Avrasya Sosyal ve Ekonomi Araştırmaları Dergisi, 4 (2017), 16-46.

Karsl, Necmi, Mutluluk ve Dindarlı, Kayseri: Kimlik Yayınları, 2018.

Karslı, Necmi, Öfke Kontrolü ve Dindarlı, Kayseri: Kimlik Yayınları, 2018.

Kartopu, Saffet, "Lise Öğrenci Ve Öğretmenlerinin Durumluk ve Sürekli Kaygı Düzeylerinin Bazı Değişkenler Açısından İncelenmesi (Kahramanmaraş Örneği)", Fırat Üniversitesi Ilahiyat Fakültesi Dergisi, 17/2 (2012), 164.

Kayıklık, Hasan, Din Psikolojisi, Adana: Karahan Kitabevi, 2011.

Kımter, Nurten - Köftegül, Özlem "Ölüm Kaygısı İle Dindarlık Arasındaki İlişsi Üzerine Bir İnceleme", Sakarya Üniversitesi İlahiyat Fakültesi Dergisi (2017), 55-82.

Kımter, Nurten, "Benlik Saygısı ve Dindarlık İlişkisi", (doktora tezi, Uludağ Üniversitesi Sosyal Bilimler Enstitüsü, 2008).

Koç, Mustafa "Yetişkinlik Döneminde Dindarlı İle Benlik Kavramı Değişkenleri Arasındaki İlişki", (doktora tezi, Uludağ Üniversitesi Sosyal Bilimler Enstitüsü, 2008).

Koç, Mustafa, "Ergenlik Döneminde Dua Ve İbadet Algılarının Ruh Sağlığına Etkileri Üzerine Bir Alan Araştırması", Sakarya Üniversitesi Illahiyat Fakültesi Dergisi, 10 (2004), 115157.

Koenig, Harold G.- Larson, David B. "Religion and mental health: evidence for an Association", International Review of Psychiatry, 13 (2001), 67-78. 
Kula, Naci, "Gençlik Döneminde Kimlik ve Din”, Gençlik Din ve Değerler Psikolojisi. (edt. Hayati Hökelekli), Ankara: Ankara Okulu Yayınları, 2002, 42.

Kurt, İhsan, Sinav Kaygısını Aşmanın Yolları, İstanbul: Bizim Kitaplar, 2011.

Kuşat, Ali, "Ergenlerde Allah Tasavvuru", Dindarliğın Sosyo-Psikolojisi, (ed. Ünver Günay, Celalettin Çelik), Adana: Karahan Kitabevi, 2006.

Küçükalp, Emine, "Ahlaki Yargı Gelişimi ve Dindarlık İlişkisi”, (yüksek lisans tezi, Uludağ Üniversitesi Sosyal Bilimler Enstitüsü, 2004).

Küçükalp, Emine, "Ahlaki Yargı Gelişimi ve Dindarlık İlişkisi”, (yüksek lisans tezi, Uludağ Üniversitesi Sosyal Bilimler Enstitüsü, 2004).

Larson, David B. - Larson, Susan S., "Spirituality's Potential Relevance to Physical \& Emotional Health: A Brief Review of Quantitative Research", Journal of Psychology \& Theology, 31 (2013), 37-51.

Larson, David B. v.dğr., "Associations between dimensions of religious commitment and mental health reported in the American Journal of Psychiatry and Archives of General Psychiatry: 1978-1989", American Journal of Psychiatry, (1992), 557-9.

McGuffin, Peter - Mawson, David, "Obsessive-Compulsive Neurosis: Two Identical Twin Pairs", British Journal of Psychiatry, 137/3 (1980), 285.

Mehmedoğlu, Ali Ulvi, Kişilik ve Din, İstanbul: Dem Yayınları, 2004.

Mustafa İşlek, "Ergenlerde Kaygı ve Duanın Çeşitli Değişkenler Açısından İncelenmesi", (yüksek lisans tezi, Recep Tayyip Erdoğan Üniversitesi Sosyal Bilimler Enstitüsü, 2016).

Öner, Necla, Sinav Kaygısı Envanteri El Kitabı, İstanbul: Yüksek Öğrenimde Rehberliği Tanıtma ve Rehber Yetiştirme Vakfı Yayını, 1990.

Öner, Necla, Türkiye'de Kullanılan Psikolojik Testlerden Örnekler, Boğaziçi Üniversitesi Yayınları, İstanbul, 2012.

Peker, Hüseyin, Din Psikolojisi, İstanbul: Çamlıca Yayınları, 2011.

Plotnik, Rod, Psikolojiye Giriş, (çev. Tamer Geniş), İstanbul: Kaknüs Yayınları, 2009.

Powers, Donald E., "Test Anxiety and The GRE General Test.", Report No. 86-45, Princeton, NJ: Educational Testing Service, 1986.

Razali Salleh Mohd. - Aminah, Kassim - Khan, Umeed Ali "Religious-Cultural Psychotherapy in The Management Of Anxiety Patients", Transcultural Psychiatry 39/1 (2002), 130136.

Reiland, Sarah- Lauterbach, Dean, "Effects of Trauma And Religiosity on Self-Esteem" Psychological Report, 102 (2008), 779-90.

Sevindik, Durmuş, "Orta Yaş Dönemi Bireylerde Dindarlık-Mutluluk İlişkisi: Denizli Örneği" (yüksek lisans tezi, Süleyman Demirel Üniversitesi Sosyal Bilimler Enstitüsü, 2015).

Seyhan, Beyazıt Yaşar, "Dini Şuur Ölçeği: Geçerlik ve Güvenirlik Çalışması", EKEV Akademi Dergisi, 19/61 (2015), 399-406.

Smoller, Jordan W. - Block, Stefanie R.- Young, Mirella M. "Genetics Of Anxiety Disorders: The Complex Road From DSM To DNA" Depress Anxiety, 26/11 (2009), 965-975

Smoller, Jordan W. - Cerrato, Felecia E. - Weatherall, Sarah L., "The Genetics Of Anxiety Disorders", Anxiety Disorders, (edt. Kerry J. Ressler, Daniel S. Pine, Barbara Olasov Rothbaum), New York: Oxford University Press, 2015.

Stevens, Holly Hazlett, Psychological Approaches to Generalized Anxiety Disorder, New York: Springer, 2008.

Şengül, Fatma, "Dindarlık ve Ruh Sağlığı İlişkisi" (yüksek lisans tezi, Marmara Üniversitesi Sosyal Bilimler Enstitüsü, 2007). 
Torgersen Svenn, "Genetic Factors in Anxiety Disorders", Arch Gen Psychiatry, 40/10 (1983), 1085-9.

Toufexis, Donna - Hammack, Sayamwong E., Anti-Anxiety Drugs, New York: Chelsea House Publishers, 2006.

Tugan, Süleyman Ertuğrul, "Lise Öğrencilerinde Sınav Kaygısı ve Akademik Başarı İlişkisi", Karaelmas Journal of Educational Sciences, 3 (2015), 98-106.

Watson, John B., Behaviorism, New York: Routledge, 2017.

William S. Harris, v.dğr., "A Randomized, Controlled Trial Of The Effects Of Remote, Intercessory Prayer On Outcomes In Patients Admitted To The Coronary Care Unit", Arch Intern Med, 159 (1999), 2273-8.

Yakut, Selahattin, "Öğretmenlerde Yabancılaşma, Yalnızlık ve Dindarlık İlişkisi: Polatlı Örneği" (doktora tezi, Süleyman Demirel Üniversitesi Sosyal Bilimler Enstitüsü, 2016).

Yaparel, Recep, "Dua, Psikolojik Bir Yaklaşım”, Dokuz Eylül Üniversitesi İlahiyat Fakültesi Dergisi, (1995), 9.

Yapıcl, Asım, "Güdü ve İçerik Açısından Çocuklarda Dua ve Dualara Yansıyan Sorunlar", ÇÜIFD, 5/2 (2005), 58-94.

Yapıcı, Asım-Kayıklık, Hasan, "Ruh Sağlı̆̆ı Bağlamında Dindarlığın Özsaygı ve Kaygı ile İlișkisi: Çukurova Üniversitesi Örneği” Değerler Eğitimi Dergisi, $3 / 9$ (2005), 177-206.

Yıldız, Murat, "Dinî Hayat İle Ölüm Kaygısı Arasındaki İlişki Zerine Bir Araştırma", (doktora tezi, Dokuz Eylül Üniversitesi Sosyal Bilimler Enstitüsü, 1998).

Yoğurtçu, Fatma, "Yetişkinlerde Dindarlık ve Ruh Sağlı̆̆ı", (yüksek lisans Tezi, Sakarya Üniversitesi Sosyal Bilimler Enstitüsü, 2009).

Zeidner, Moshe - Matthews, Gerald, Anxiety 101, New York: Springer Publishing, 2010.

Zeidner, Moshe, Test Anxiety, The State of The Art, New York: Kluwer Academic Publishers, 1998.

Pedagog Sitesi, "Sınav Kaygısı ile Nasıl Başa Çıkılır", http://pedagogsitesi.com/sinav-kaygisinedir-nasil-basa-cikilir/ (Erişim: 26 Kasım 2018) 